Supporting Information for

\title{
Two-State Reactivity in Iron-Catalyzed Alkene Isomerization Confers $\sigma$-Base Resistance
}

Sean A. Lutz, Anne K. Hickey, Yafei Gao, Chun-Hsing Chen and Jeremy M. Smith 


\section{Table of Contents}

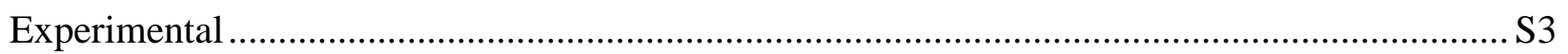

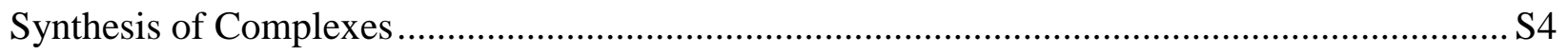

Kinetics and Mechanistic Experiments........................................................................ S10

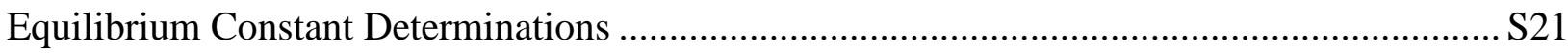

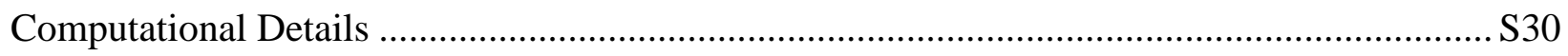

Crystallographic Data Collection....................................................................................... S39

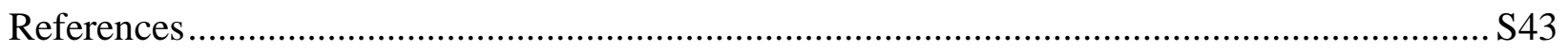




\section{Experimental}

General Considerations. All manipulations were performed under a nitrogen atmosphere by standard Schlenk techniques or in an MBraun glove box. Glassware was dried at $130{ }^{\circ} \mathrm{C}$ overnight before cooling under a dynamic vacuum in an antechamber. Manipulations involving high vacuum and reactive gases were performed using standard Schlenk techniques in a single-manifold glass line. Diethyl ether $\left(\mathrm{Et}_{2} \mathrm{O}\right)$, tetrahydrofuran $(\mathrm{THF})$, toluene, and pentane were purified by a Glass Contour solvent purification system. Celite was dried overnight at $130{ }^{\circ} \mathrm{C}$ under vacuum. The compounds $\mathrm{Ph}_{2} \mathrm{~B}\left({ }^{t} \mathrm{BuIm}\right)_{2} \mathrm{FeCl}(\mathrm{THF})^{1}$ and $\mathrm{Li}\left(\mathrm{CH}_{2}{ }^{\mathrm{t}} \mathrm{Bu}\right)^{2}$ were prepared by literature methods. All other chemicals were purchased and used as received. ${ }^{1} \mathrm{H}$ NMR spectroscopic data were recorded on Varian spectrometers. Solution magnetic susceptibilities were determined by Evans' method. ${ }^{3}$ UV-Vis spectroscopic data were collected on an Agilent Technologies Cary $60 \mathrm{UV}$-Vis instrument. IR spectra were recorded with a Perkin Elmer spectrophotometer. Mössbauer spectra were recorded on a SEE Co spectrometer. The sample temperature was controlled using a SVT400 Dewar from Janis equipped with a Lake Shore 255 Temperature Controller. The isomer shifts are reported relative to the centroid of the spectrum of $\alpha$-Fe at $298 \mathrm{~K}$. Samples were prepared by grinding crystallized material into a fine powder and then mounting in a cup, plugged with a fitted O-ring sealed cap. Data analysis was performed using the program WMOSS ${ }^{4}$ and quadrupole doublets were fitted to Lorentzian lineshapes. Mass spectrometry measurements were made using an Agilent 1200 HPLC-6130 MSD spectrometer. Elemental analysis was conducted by Midwest Microlab, LLC (Indianapolis, IN). 


\section{Synthesis of Complexes}

$\mathbf{P h}_{2} \mathbf{B}\left({ }^{t} \mathbf{B u I m}\right)_{2} \mathbf{F e C H}{ }_{2}{ } \mathbf{B u}$ (1). A vial was charged with $\mathrm{Ph}_{2} \mathrm{~B}\left({ }^{t} \mathrm{BuIm}\right)_{2} \mathrm{FeCl}(\mathrm{THF})(71 \mathrm{mg}, 0.12$ mmol) and pentane $(10 \mathrm{~mL}) \cdot \mathrm{LiCH}_{2}{ }^{\mathrm{B}} \mathrm{Bu}(10 \mathrm{mg}, 0.13 \mathrm{mmol})$ was added as a solid, affording a yellow slurry which was stirred for $30 \mathrm{~min}$, and filtered through Celite. The yellow filtrate was dried under vacuum, giving $\mathrm{Ph}_{2} \mathrm{~B}\left({ }^{t} \mathrm{BuIm}\right)_{2} \mathrm{FeCH}_{2}{ }^{t} \mathrm{Bu}$ (1) as a yellow powder (63 mg, $95 \%$ yield). Crystals suitable for X-ray diffraction were grown by slow evaporation of pentane at room temperature. ${ }^{1} \mathrm{H}$ NMR $\left(400 \mathrm{MHz}, \mathrm{C}_{6} \mathrm{D}_{6}, 25^{\circ} \mathrm{C}\right): 102.3(2 \mathrm{H}, \mathrm{Im}-H) ; 61.2\left(9 \mathrm{H}, \mathrm{CH}_{2}{ }^{t} \mathrm{Bu}\right) ; 45.7(2 \mathrm{H}$, $\mathrm{Ph}-H) ; \quad-62.2 \quad\left({ }^{t} \mathrm{Bu}-H\right) . \quad \mu_{\mathrm{eff}} \quad$ (Evans', $\left.\mathrm{C}_{6} \mathrm{D}_{6}, 298 \mathrm{~K}\right): 5.0(3) \quad \mu_{\mathrm{B}} . \quad$ Anal. Calcd. for $\mathrm{C}_{31} \mathrm{H}_{43} \mathrm{BFeN}_{4} \cdot 0.5 \mathrm{LiCl}: \mathrm{C}, 66.54, \mathrm{H}$ 7.75, N 10.01. Found C 66.05, H 7.75, N 10.00.

$[K($ 2.2.2-cryptand $)]\left[\mathrm{Ph}_{2} \mathrm{~B}\left({ }^{t} \mathbf{B u I m}\right)_{2} \mathrm{FeCH}_{2}{ }^{t} \mathrm{Bu}\left(\mathbf{N}_{2}\right)\right] \quad$ (2). A vial was charged with $\mathrm{Ph}_{2} \mathrm{~B}\left({ }^{t} \mathrm{BuIm}\right)_{2} \mathrm{FeCH}_{2}{ }^{t} \mathrm{Bu}(\mathbf{1})(63 \mathrm{mg}, 0.12 \mathrm{mmol})$ and $\mathrm{THF}(2 \mathrm{~mL}) . \mathrm{KC}_{8}(9 \mathrm{mg}, 0.12 \mathrm{mmol})$ and 2.2.2-cryptand (38 $\mathrm{mg}, 0.12 \mathrm{mmol}$ ) were added as solids, and the slurry was stirred $2 \mathrm{~h}$, gradually turning red. The slurry was filtered through Celite, giving a red solution that was layered with pentane and stored at $-35^{\circ} \mathrm{C}$ overnight. The mother liquor was decanted, giving red crystals of $[\mathrm{K}(2.2 .2$-cryptand $)]\left[\mathrm{Ph}_{2} \mathrm{~B}\left({ }^{t} \mathrm{BuIm}\right)_{2} \mathrm{FeCH}_{2}{ }^{\mathrm{t}} \mathrm{Bu}\left(\mathrm{N}_{2}\right)\right]$ (2) which were dried under vacuum (73 mg, $63 \%$ yield). Crystals suitable for X-ray diffraction were grown from a concentrated THF solution layered with pentane left at room temperature for 3 h. $v_{\mathrm{N} 2}\left(\mathrm{KBr}\right.$ pellet) $1897 \mathrm{~cm}^{-1}$. $\mu_{\mathrm{eff}}$ (Evans', THF- $\left.\mathrm{d}_{8}, 298 \mathrm{~K}\right): 4.2(3) \mu_{\mathrm{B}}$. THF solutions of complex 2 were found to be thermally unstable over several hours. Solutions and solids were stored at $-35{ }^{\circ} \mathrm{C}$. Anal. Calcd. for $\mathrm{C}_{49} \mathrm{H}_{79} \mathrm{BFeKN}_{8} \mathrm{O}_{6}$ : C 59.93, H 8.11, N 11.41. Found C 59.60, H 7.98, N 11.39. 
[K(2.2.2-cryptand $)]\left[\mathrm{Ph}_{2} \mathrm{~B}\left({ }^{t} \mathrm{BuIm}\right)_{2} \mathrm{FeCH}_{2}{ }^{t} \mathbf{B u}\left(\eta^{2}-\mathrm{PhCCPh}\right)\right]$ (3). A vial was charged with [K(2.2.2-cryptand) $]\left[\mathrm{Ph}_{2} \mathrm{~B}\left({ }^{t} \mathrm{BuIm}\right){ }_{2} \mathrm{FeCH}_{2}{ }^{\mathrm{t}} \mathrm{Bu}\left(\mathrm{N}_{2}\right)\right]$ (2) $(68 \mathrm{mg}, 0.07 \mathrm{mmol})$ and $\mathrm{THF}(2 \mathrm{~mL})$. Diphenylacetylene $(\mathrm{PhCCPh}, 13 \mathrm{mg}, 0.07 \mathrm{mmol})$ was added as a solid. The reaction solution immediately effervesced and turned from red to puce. The solution was layered with pentane ( 2 $\mathrm{mL}$ ) and stored at $-35^{\circ} \mathrm{C}$ overnight. Decanting the mother liquor and drying the remaining crystals afforded $[\mathrm{K}(2.2 .2$-cryptand $)]\left[\mathrm{Ph}_{2} \mathrm{~B}\left({ }^{t} \mathrm{BuIm}\right){ }_{2} \mathrm{FeCH}_{2}{ }^{\mathrm{t}} \mathrm{Bu}\left(\eta^{2}-\mathrm{PhCCPh}\right)\right](3)$ as X-ray quality crystals (51 mg, 65\% yield). ${ }^{1} \mathrm{H}$ NMR (400 MHz, THF- $\left.d 8,25^{\circ} \mathrm{C}\right): 34.5(2 \mathrm{H}, \mathrm{Im}-H), 23.8(2 \mathrm{H}, \mathrm{Ph}-H) ; 22.5$ (2H, Im- $H) ; 13.3$ (2H, PhB); 11.7 (PhB); 7.5 (1H, Ph-H); 5.6 (3H, Ph-H); 4.7 (6H, 2.2.2-cryptand); $2.7\left(9 \mathrm{H}, \mathrm{CH}_{2}{ }^{t} \mathrm{Bu}\right) ;-7.7\left(18 \mathrm{H},{ }^{t} \mathrm{Bu}-H\right) . v_{\mathrm{CC}}(\mathrm{KBr}$ pellet $) 1769 \mathrm{~cm}^{-1}$. $\mu_{\mathrm{eff}}$ (Evans', THF- $\left.d_{8}, 298 \mathrm{~K}\right)$ :

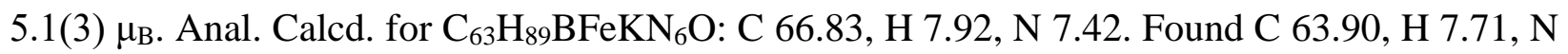
7.16. Samples of this complex consistently analyzed low for carbon.

\section{Synthesis of 1-hexene-3.3-D2}

The compound was prepared by the procedure reported by Bartok and coworkers. ${ }^{5}$

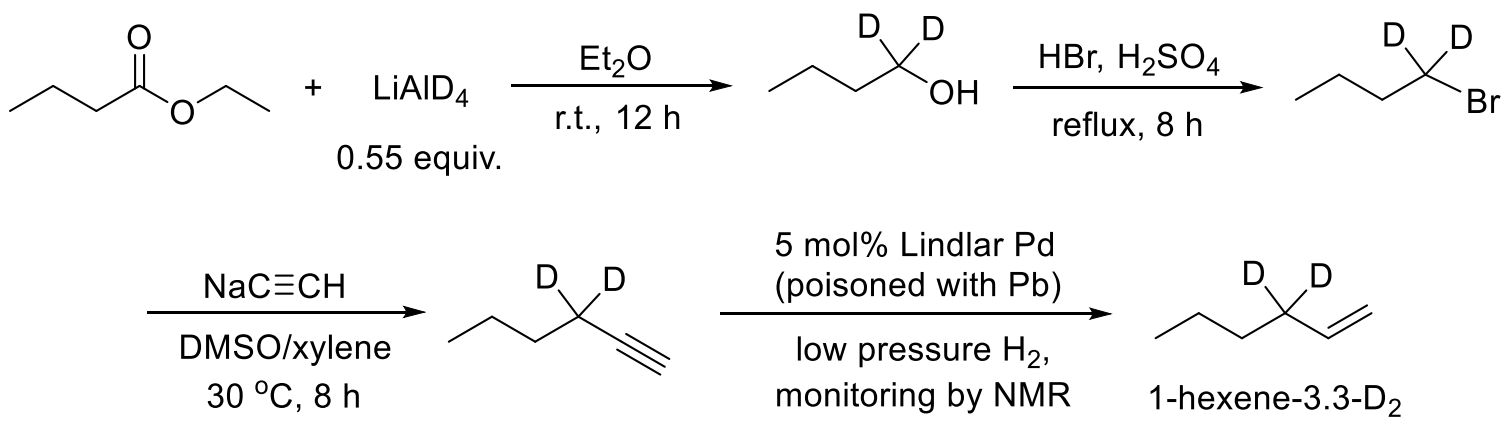




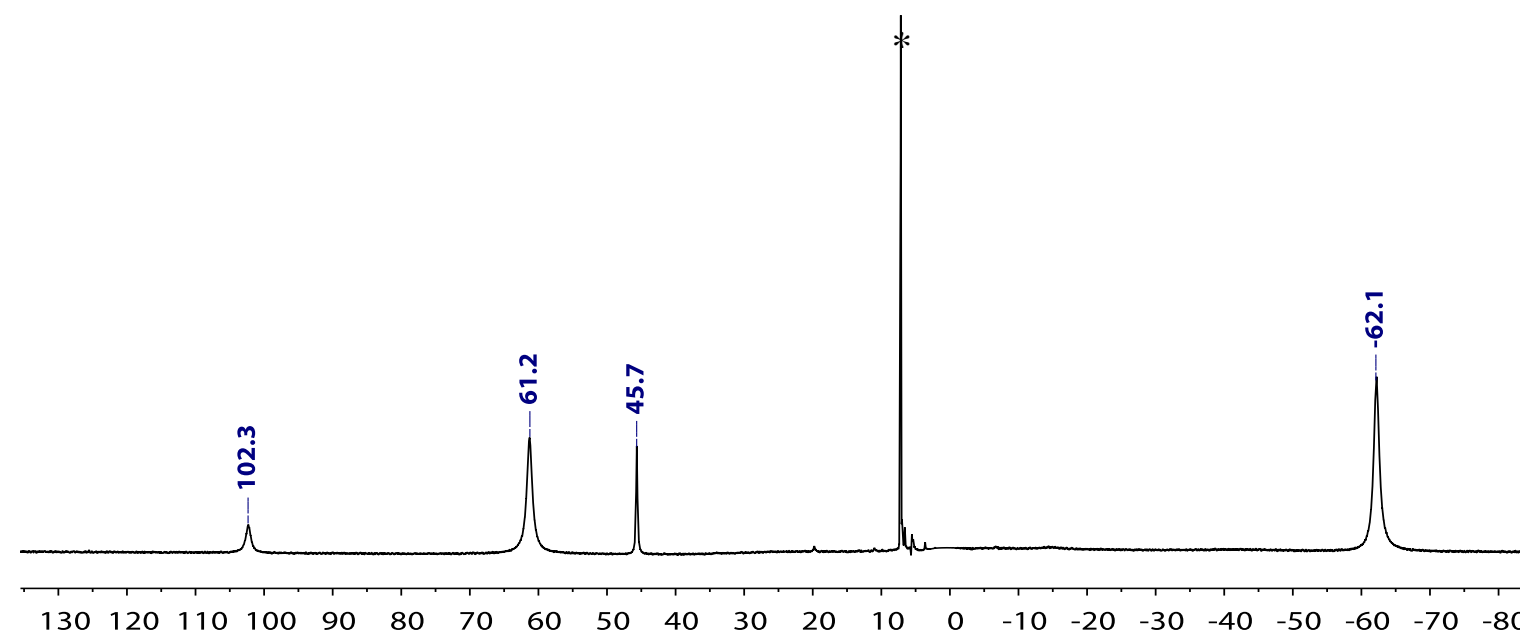

Figure S1. ${ }^{1} \mathrm{H}$ NMR spectrum $\left(400 \mathrm{MHz}, 25^{\circ} \mathrm{C}, \mathrm{C}_{6} \mathrm{D}_{6}(*)\right)$ of $\mathbf{1}$.

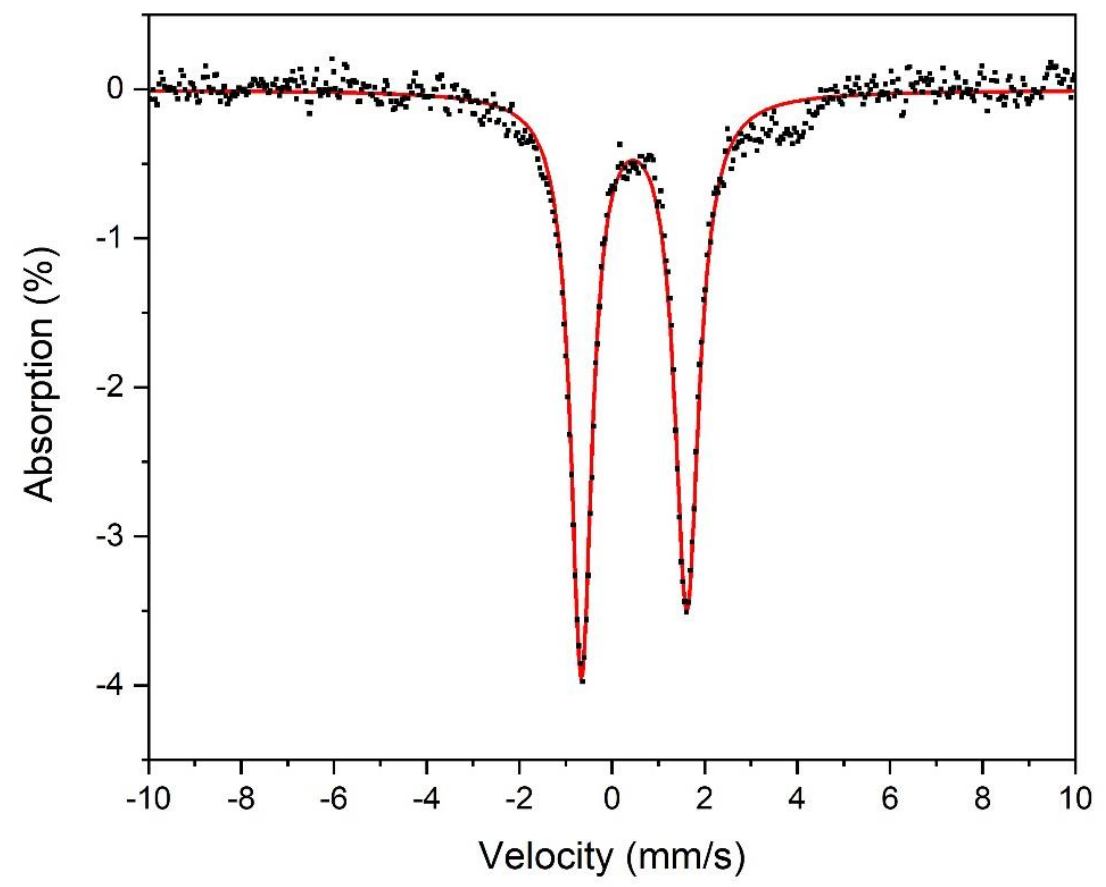

Figure S2. Solid state ${ }^{57} \mathrm{Fe}$ Mössbauer spectrum of $\left.\mathrm{Ph}_{2} \mathrm{~B}\left({ }^{t} \mathrm{BuIm}\right)_{2} \mathrm{FeCH}_{2}{ }^{t} \mathrm{Bu} 1\right)$ at $80 \mathrm{~K}$. 


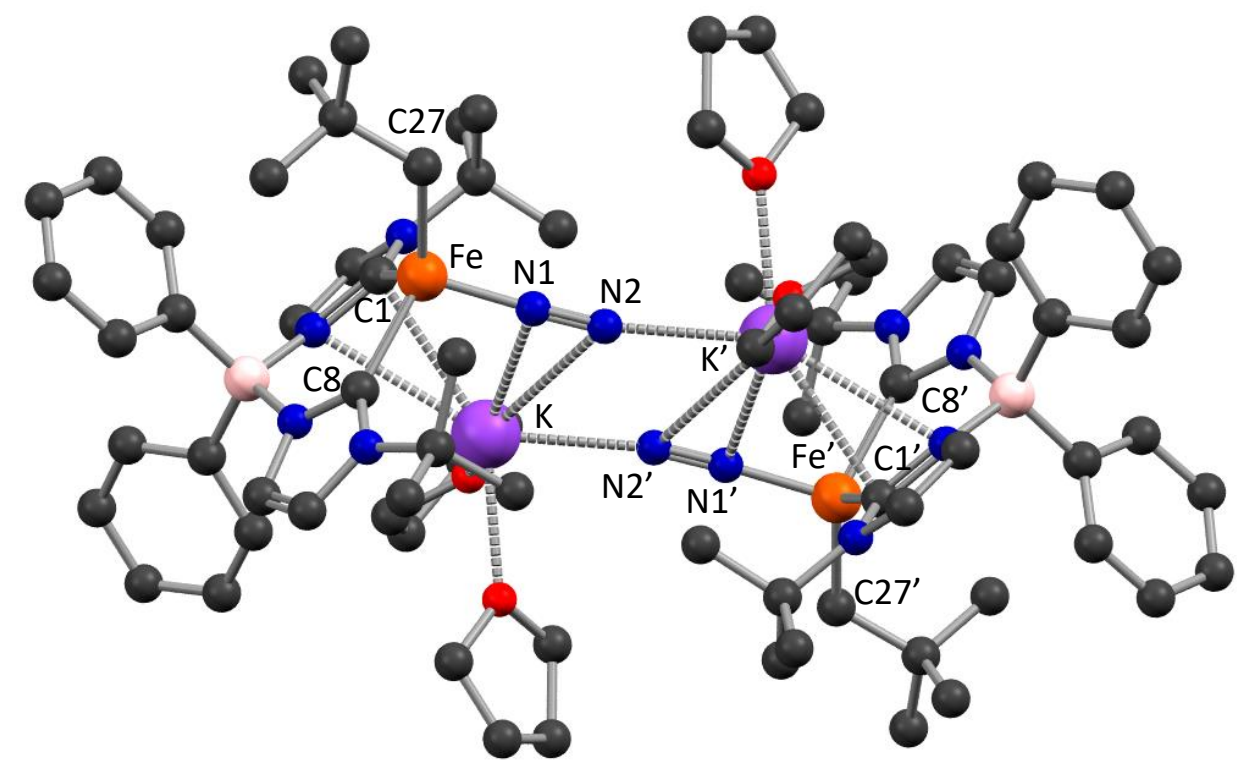

Figure S3. Connectivity of $\left\{[\mathrm{K}]\left[\mathrm{Ph}_{2} \mathrm{~B}\left({ }^{t} \mathrm{BuIm}\right)_{2} \mathrm{FeCH}_{2}{ }^{\mathrm{B}} \mathrm{Bu}\left(\mathrm{N}_{2}\right)\right](\mathrm{THF})_{2}\right\}_{2}$.

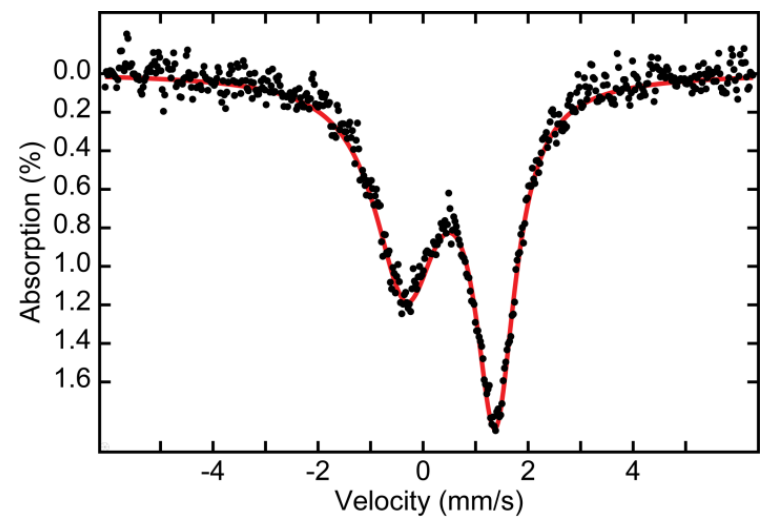

Figure S4. Solid state ${ }^{57} \mathrm{Fe} \quad$ Mössbauer spectrum of $\quad[\mathrm{K}(2.2 .2-$ cryptand $)]\left[\mathrm{Ph}_{2} \mathrm{~B}\left({ }^{t} \mathrm{BuIm}\right)_{2} \mathrm{FeCH}_{2}{ }^{t} \mathrm{Bu}\left(\mathrm{N}_{2}\right)\right](2)$ at $80 \mathrm{~K}$. 


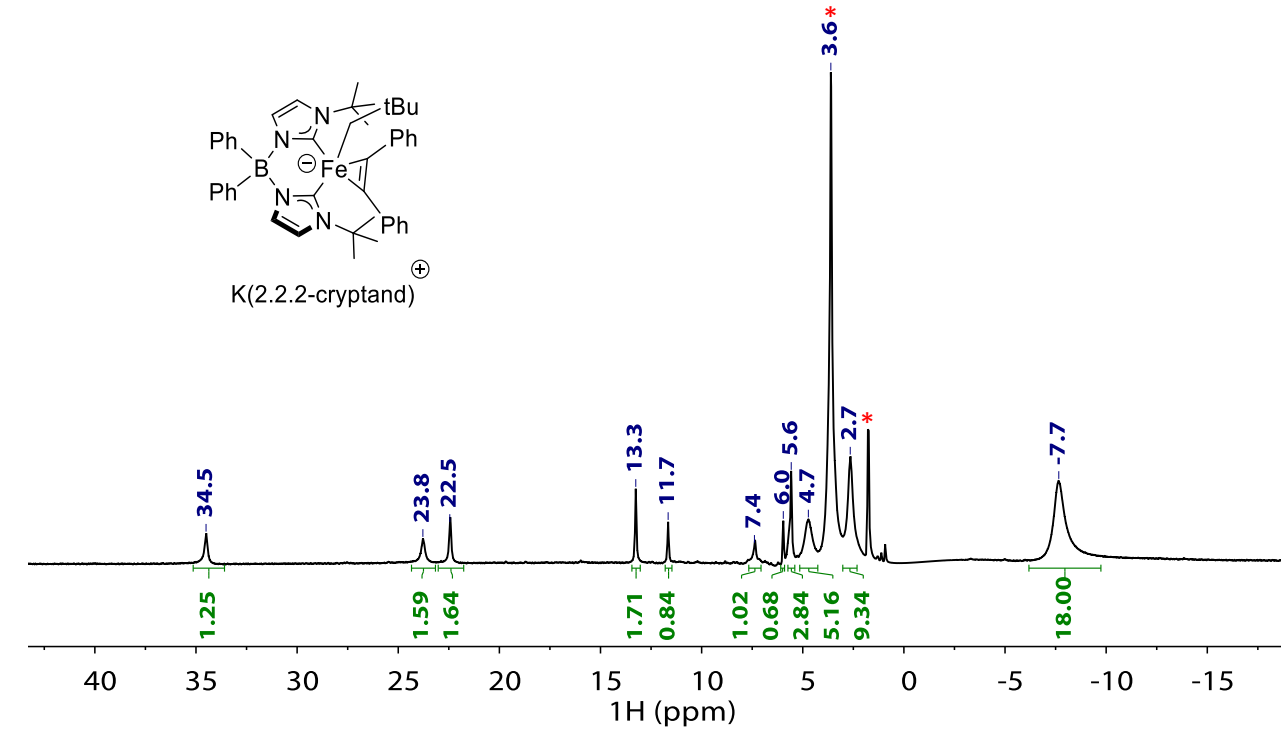

Figure S5. ${ }^{1} \mathrm{H}$ NMR spectrum $\left(400 \mathrm{MHz}, 25{ }^{\circ} \mathrm{C}\right.$, THF- $\left.d_{8}\left(^{*}\right)\right)$ of complex $[\mathrm{K}(2.2 .2-$ cryptand) $]\left[\mathrm{Ph}_{2} \mathrm{~B}\left({ }^{t} \mathrm{BuIm}\right)_{2} \mathrm{FeCH}_{2}{ }^{\mathrm{B}} \mathrm{Bu}\left(\eta^{2}-\mathrm{PhCCPh}\right)\right](3)$.

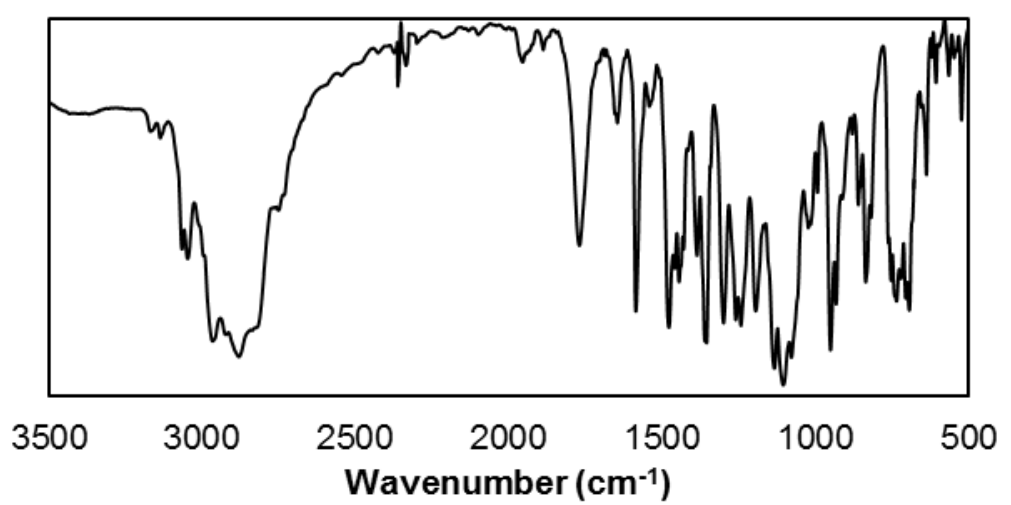

Figure S6. IR spectrum $(\mathrm{KBr})$ of complex $[\mathrm{K}(2.2 .2$-cryptand $)]\left[\mathrm{Ph}_{2} \mathrm{~B}\left({ }^{t} \mathrm{BuIm}\right){ }_{2} \mathrm{FeCH}_{2}{ }^{\mathrm{t}} \mathrm{Bu}\left(\eta^{2}-\right.\right.$ $\mathrm{PhCCPh})(3)$. 


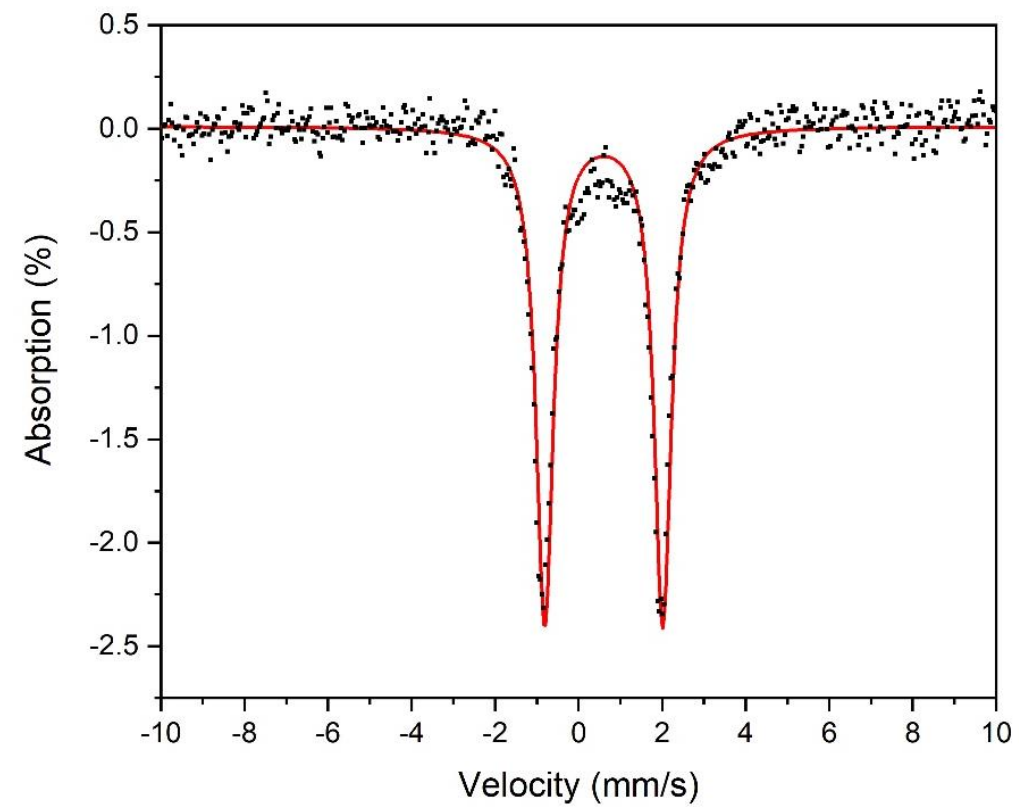

Figure S7. Solid state ${ }^{57} \mathrm{Fe} \quad$ Mössbauer spectrum of $\quad[\mathrm{K}(2.2 .2-$ cryptand $)]\left[\mathrm{Ph}_{2} \mathrm{~B}\left({ }^{t} \mathrm{BuIm}\right)_{2} \mathrm{FeCH}{ }_{2}{ }^{\mathrm{B}} \mathrm{Bu}\left(\eta^{2}-\mathrm{PhCCPh}\right)(3)\right.$ at $80 \mathrm{~K}$. 


\section{Kinetics and Mechanistic Experiments}

Isomerization of 1-hexene and 1-hexene-3.3-D2. In a typical experiment, a J. Young NMR tube was charged with $0.25 \mathrm{mmol} 1$-hexene $\left(0.3 \mathrm{~mL}\right.$ of stock solution, $0.84 \mathrm{M}$ in THF- $\left.d_{8}\right), 0.025 \mathrm{mmol}$ of $2\left(0.2 \mathrm{~mL}\right.$ of stock solution, $0.125 \mathrm{M}$ in THF- $\left.d_{8}\right)$ and $0.25 \mathrm{mmol}$ mesitylene $(30 \mathrm{mg})$ as an internal standard. The solution was monitored by ${ }^{1} \mathrm{H}$ NMR spectroscopy (400 MHz) over a period of 300 mins at $30{ }^{\circ} \mathrm{C}$ and $40{ }^{\circ} \mathrm{C}, 200$ mins at $50{ }^{\circ} \mathrm{C}$ and 80 mins at $60{ }^{\circ} \mathrm{C}$. The ratio of cis:trans 2hexene was determined by the integrals of each species observed in the ${ }^{13} \mathrm{C}\left\{{ }^{1} \mathrm{H}\right\}$ NMR spectrum collected in inverse gated decoupling mode.

Poisoning experiments were conducted similarly with $0.050 \mathrm{mmol}$ of the chosen poison.

Reaction of 2 with propene- $\boldsymbol{d}_{6}$ : A J. Young NMR tube was charged with $0.1 \mathrm{mmol} 2(98 \mathrm{mg})$ and $0.5 \mathrm{ml}$ THF- $d_{8}$. The solution was degassed by three freeze-pump-thaw cycles, then propene- $d_{6}$ was vacuum transferred into the NMR tube. The solution was monitored by ${ }^{1} \mathrm{H}$ NMR spectroscopy (400 MHz) at $40{ }^{\circ} \mathrm{C}$ over a period of 36 hours. No neopentane was observed within the detection limits of NMR.

Isomerization of 1-hexene in the presence of mercury: A J. Young NMR tube was charged with $0.25 \mathrm{mmol}$ 1-hexene ( $21 \mathrm{mg}), 0.025 \mathrm{mmol} 2(25 \mathrm{mg}), 0.5 \mathrm{ml}$ THF- $d_{8}$, a drop of mercury and 0.25 mmol mesitylene $\left(30 \mathrm{mg}\right.$ ) as an internal standard. The solution was monitored by ${ }^{1} \mathrm{H}$ NMR spectroscopy $(400 \mathrm{MHz})$ at $40{ }^{\circ} \mathrm{C}$, with no difference in the rate of 1-hexene consumption. 


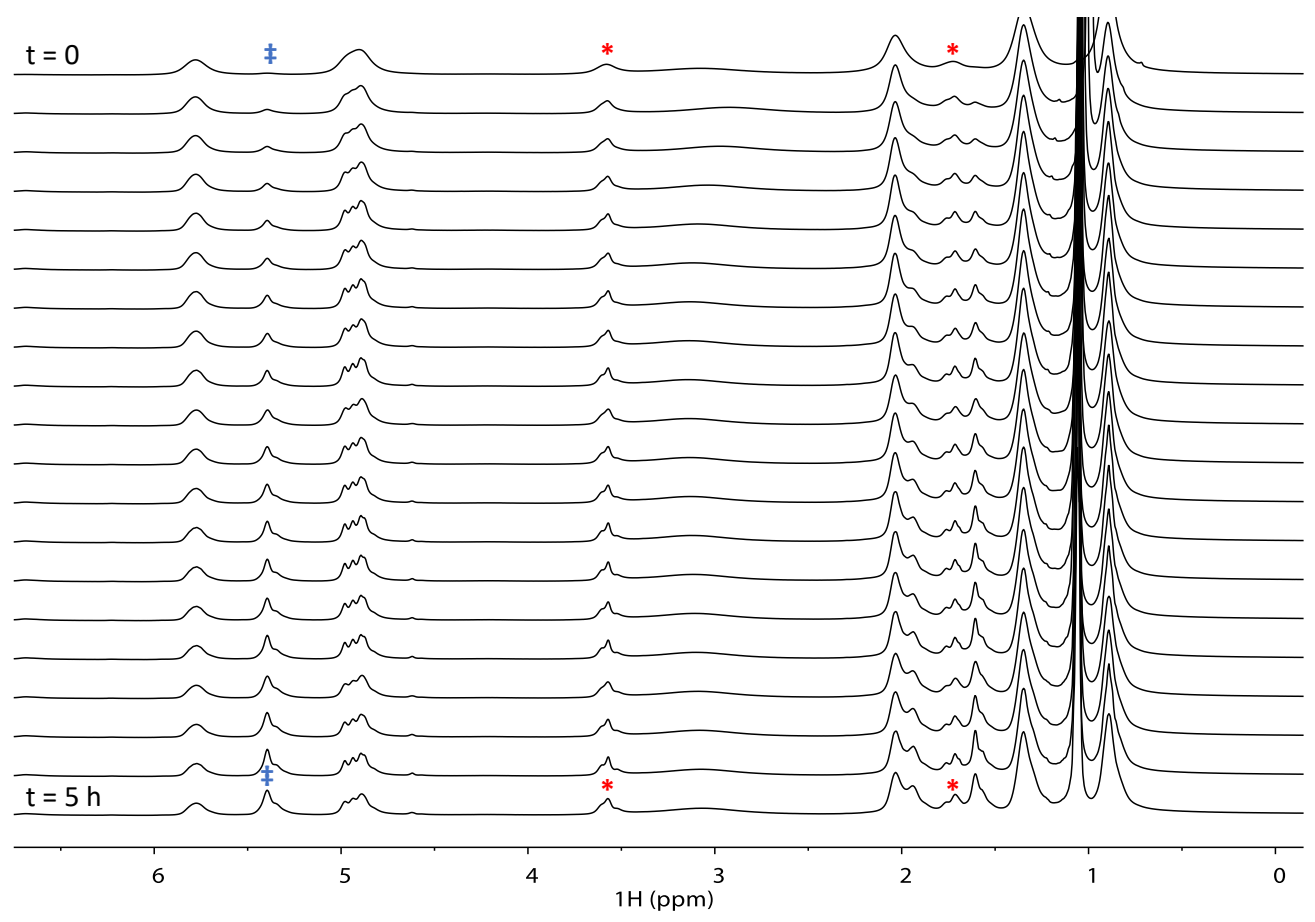

Figure S8. Example array spectra $\left(400 \mathrm{MHz}, 25{ }^{\circ} \mathrm{C}\right.$, THF- $d_{8}(*), 15$ minute increments) of isomerization of 1 -hexene by complex 2 . The signal for 2 -hexene formation is indicated at $5.4 \mathrm{ppm}$ $(\$)$. 


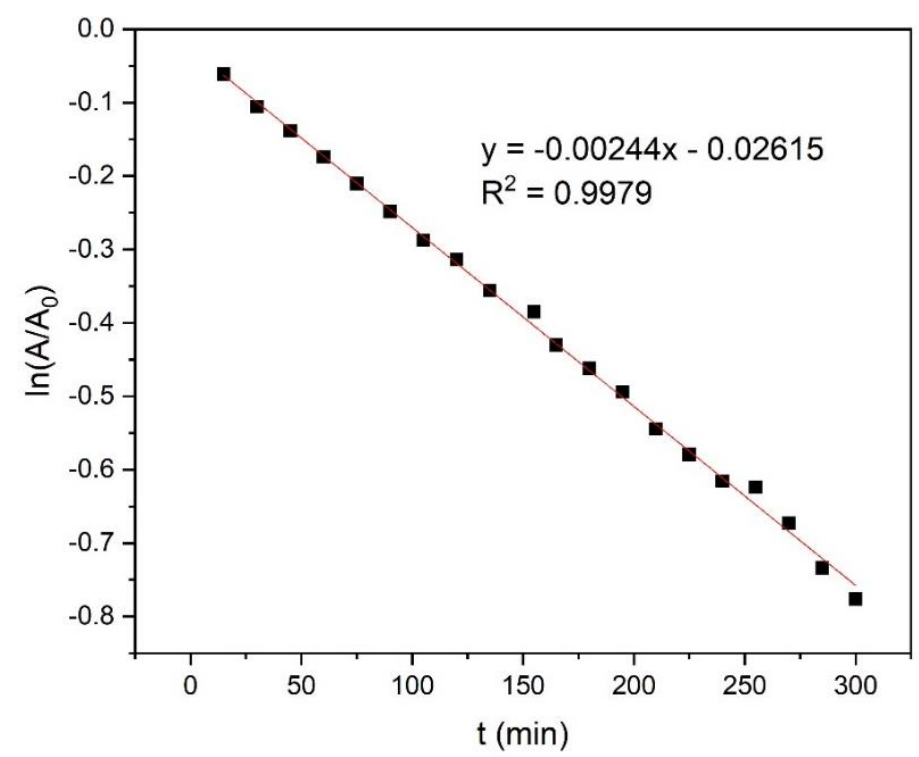

Figure S9. First-order dependence of the change in 1-hexene concentration in the presence of 10 mol\% complex 2 in THF- $d_{8}$ at $30{ }^{\circ} \mathrm{C}$. The rate constant $\left(\mathrm{k}_{\mathrm{obs}}\right)$ is $4.067 \times 10^{-5} \mathrm{~s}^{-1}$.

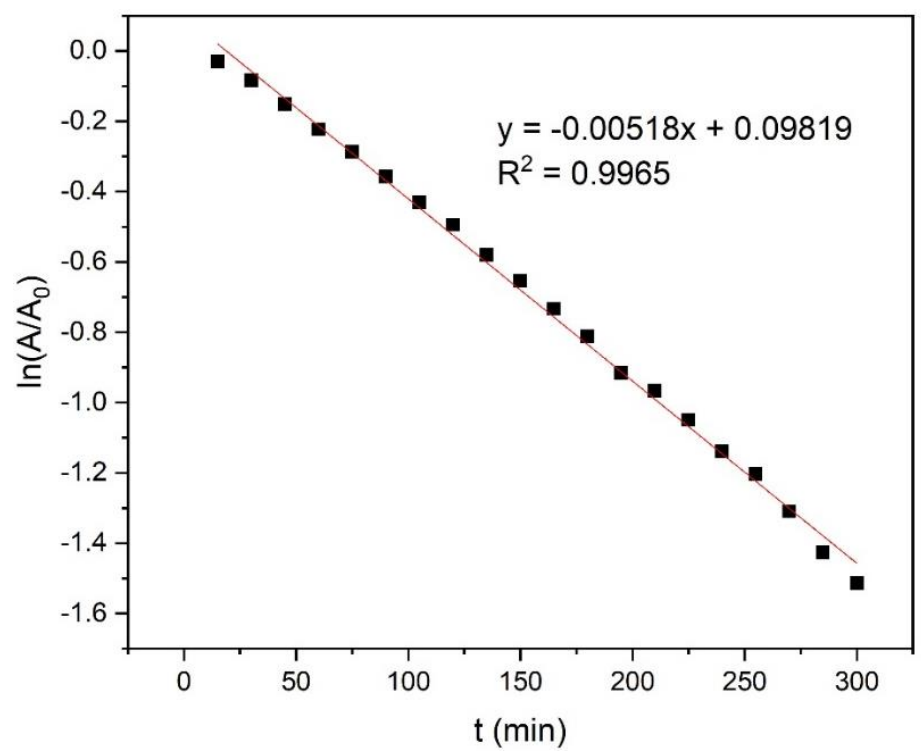

Figure S10. First-order dependence of the change in 1-hexene concentration in the presence of 10 mol\% complex 2 in THF- $d_{8}$ at $40{ }^{\circ} \mathrm{C}$. The rate constant $\left(\mathrm{k}_{\mathrm{obs}}\right)$ is $8.633 \times 10^{-5} \mathrm{~s}^{-1}$. 


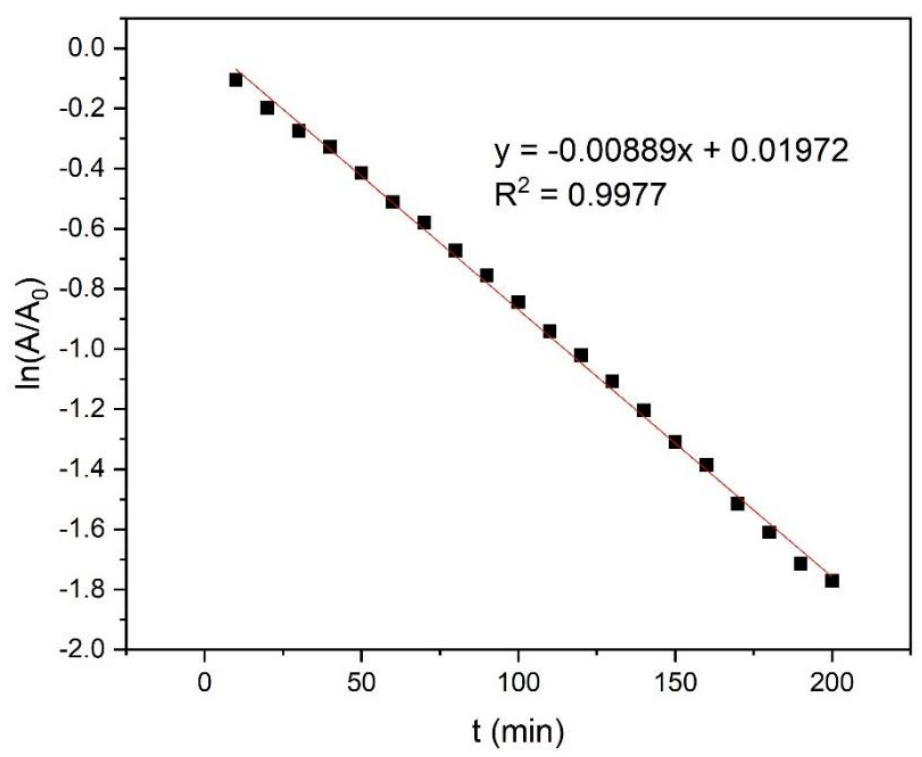

Figure S11. First-order dependence of the change in 1-hexene concentration in the presence of 10 mol\% complex 2 in THF- $d_{8}$ at $50^{\circ} \mathrm{C}$. The rate constant $\left(\mathrm{k}_{\text {obs }}\right)$ is $1.4817 \times 10^{-4} \mathrm{~s}^{-1}$.

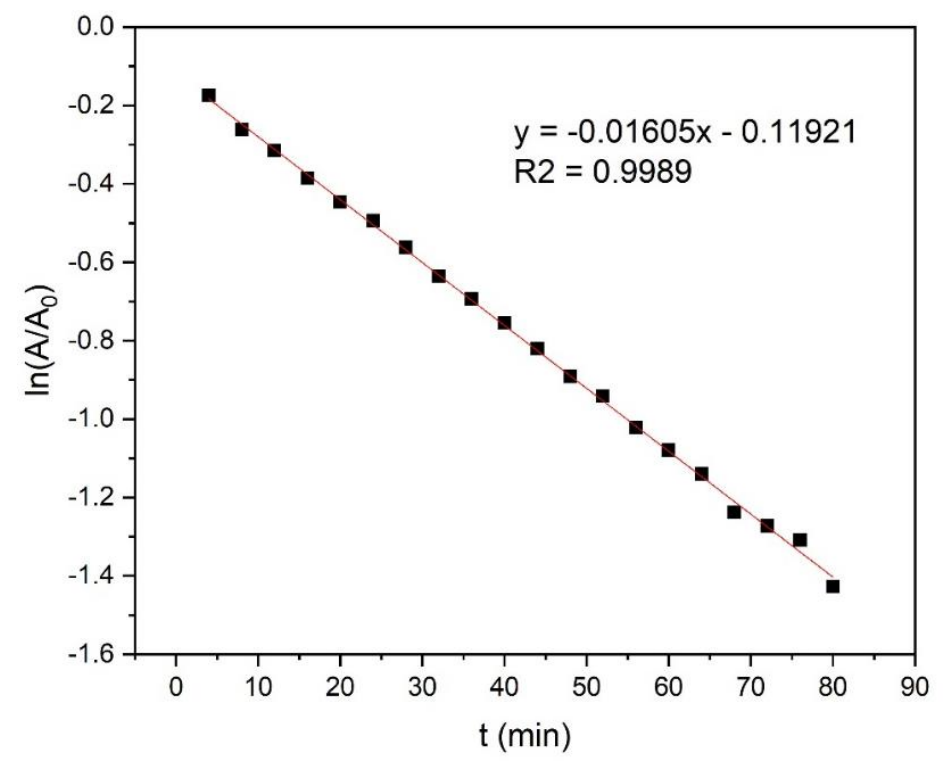

Figure S12. First-order dependence of the change in concentration of 1-hexene in the presence of 10 mol\% complex 2 in THF- $d_{8}$ at $60{ }^{\circ} \mathrm{C}$. The rate constant $\left(\mathrm{k}_{\mathrm{obs}}\right)$ is $2.675 \times 10^{-4} \mathrm{~s}^{-1}$. 


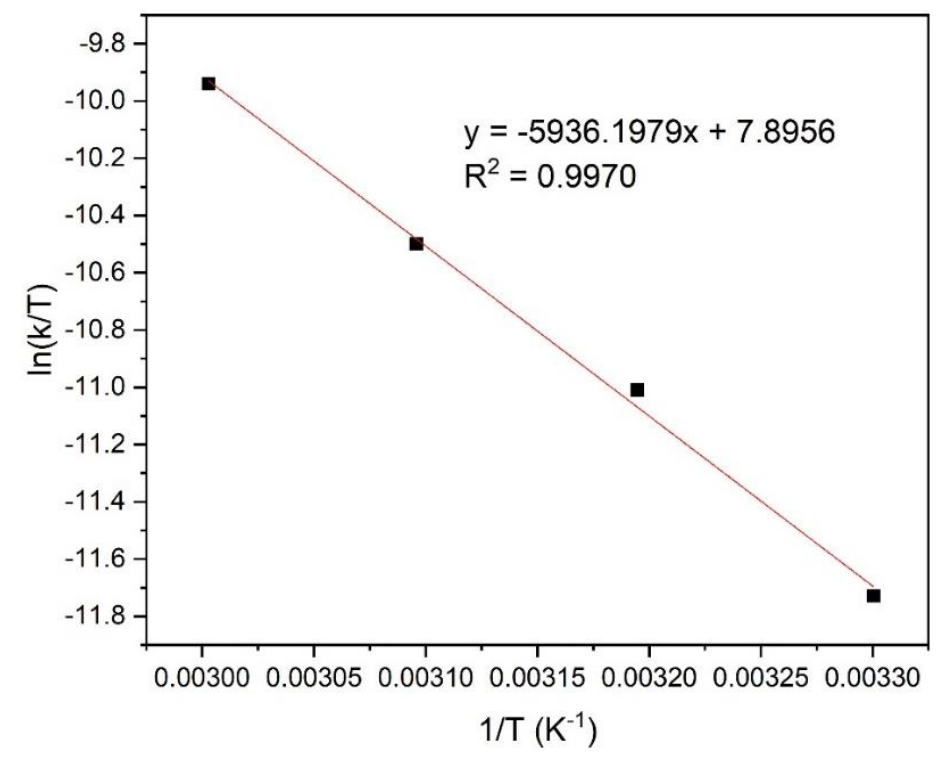

Figure S13. Eyring plot for the isomerization of 1-hexene in the presence of $10 \mathrm{~mol} \%$ complex 2 in THF- $d_{8}$ at temperature range $30-60{ }^{\circ} \mathrm{C}$, yielding $\Delta H^{\ddagger}=11.8 \pm 0.5 \mathrm{kcal} / \mathrm{mol}, \Delta S^{\ddagger}=-31.5 \pm 1.5$ $\mathrm{cal} / \mathrm{mol} / \mathrm{K}$. At $40^{\circ} \mathrm{C}, \Delta G^{\ddagger}=21.6 \pm 1.0 \mathrm{kcal} / \mathrm{mol}$.

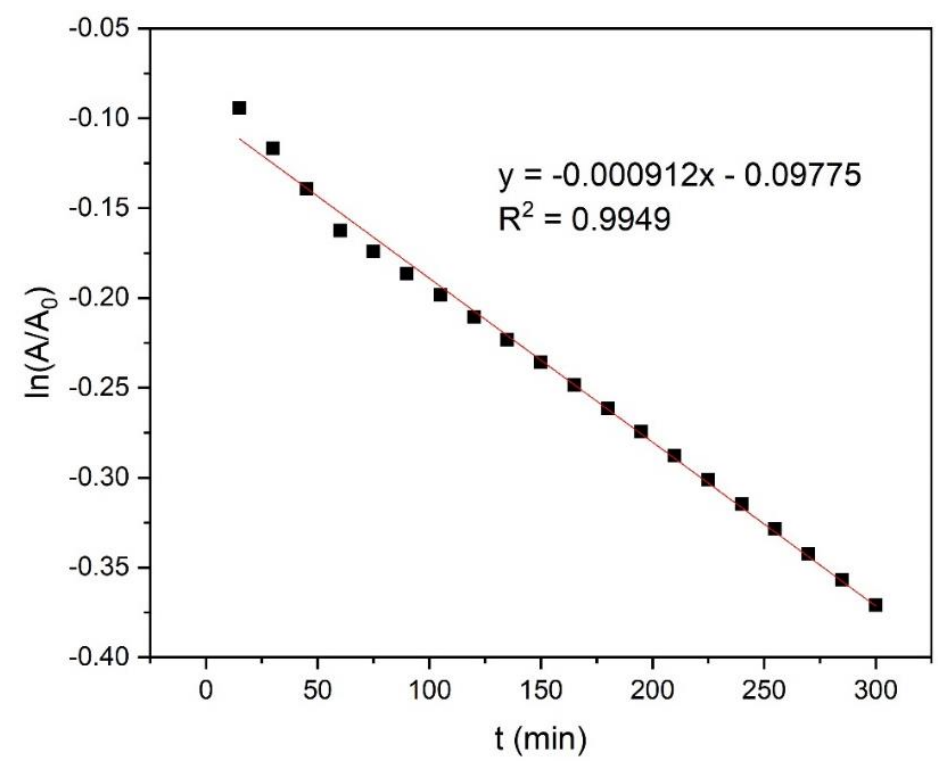

Figure S14. First-order dependence of the change in concentration of 1-hexene-3,3- $\mathrm{D}_{2}$ in the presence of $10 \mathrm{~mol} \%$ complex 2 in THF- $d_{8}$ at $30{ }^{\circ} \mathrm{C}$. The rate constant $\left(\mathrm{k}_{\mathrm{obs}}\right)$ is $1.52 \times 10^{-5} \mathrm{~s}^{-1}$. 


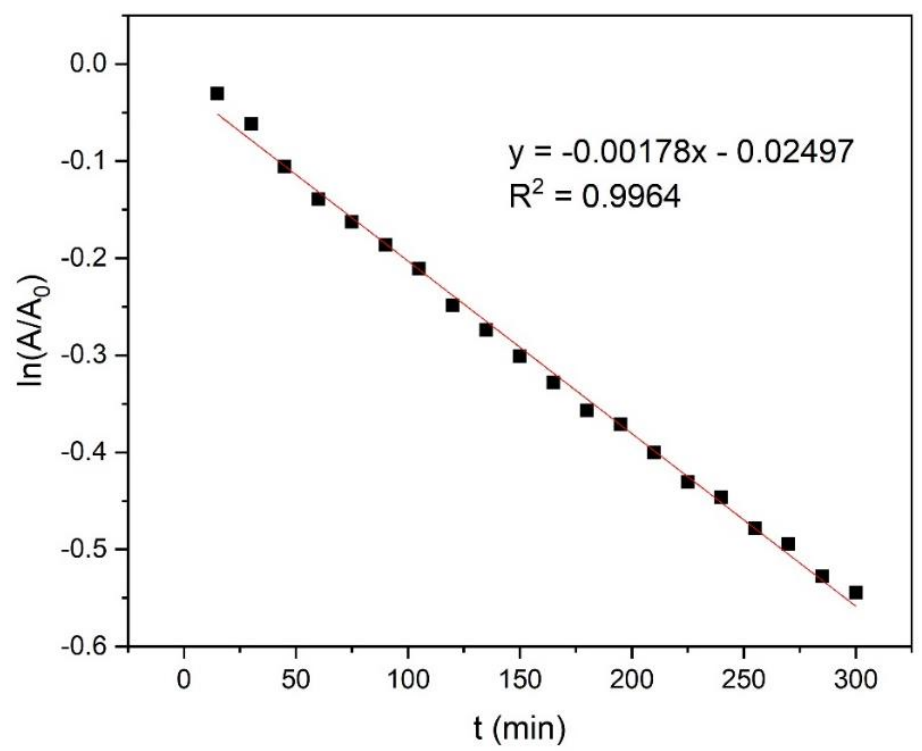

Figure S15. First-order dependence of the change in concentration of 1-hexene-3,3- $\mathrm{D}_{2}$ in the presence of $10 \mathrm{~mol} \%$ complex 2 in THF- $d_{8}$ at $40{ }^{\circ} \mathrm{C}$. The rate constant $\left(\mathrm{k}_{\text {obs }}\right)$ is $2.967 \times 10^{-5} \mathrm{~s}^{-1}$.

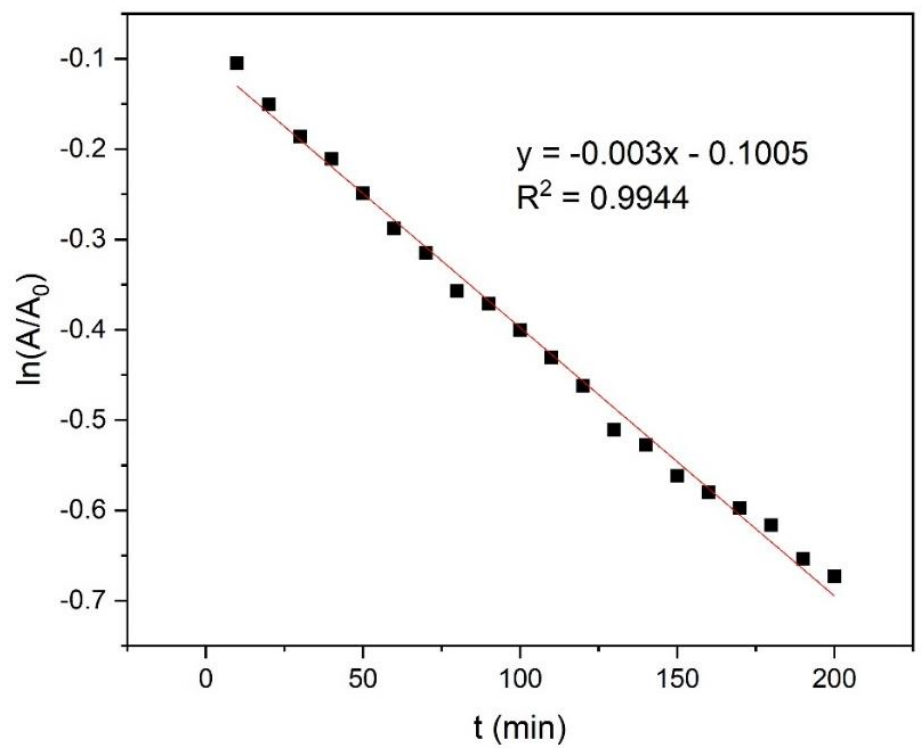

Figure S16. First-order time dependence of the change in concentration of 1-hexene-3,3- $\mathrm{D}_{2}$ in the presence of $10 \mathrm{~mol} \%$ complex 2 in THF- $d_{8}$ at $50{ }^{\circ} \mathrm{C}$. The rate constant $\left(\mathrm{k}_{\mathrm{obs}}\right)$ is $5 \times 10^{-5} \mathrm{~s}^{-1}$. 


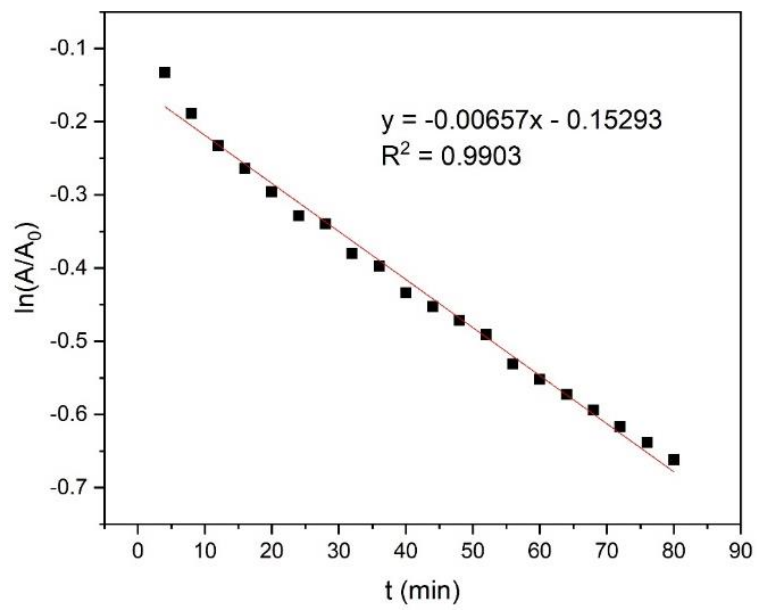

Figure S17. First-order dependence of the change in concentration of 1-hexene-3,3- $\mathrm{D}_{2}$ in the presence of $10 \mathrm{~mol} \%$ complex 2 in THF- $d_{8}$ at $60{ }^{\circ} \mathrm{C}$. The rate constant $\left(\mathrm{k}_{\text {obs }}\right)$ is $1.095 \times 10^{-4} \mathrm{~s}^{-1}$.

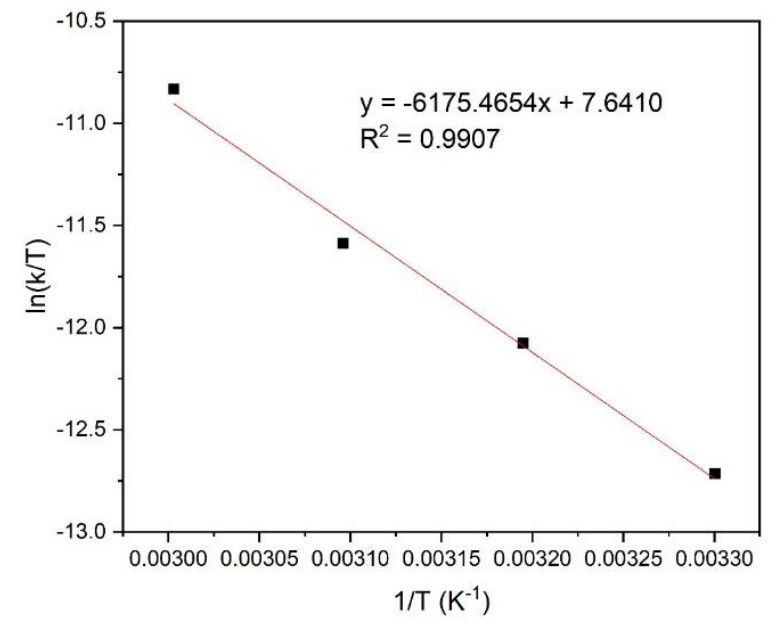

Figure S18. Eyring plot for the isomerization of 1-hexene-3,3- $\mathrm{D}_{2}$ in the presence of $10 \mathrm{~mol} \%$ complex 2 in THF- $d_{8}$ at temperature range $30-60{ }^{\circ} \mathrm{C}$, providing $\Delta H^{\ddagger}=12.3 \pm 0.8 \mathrm{kcal} / \mathrm{mol}, \Delta S^{\ddagger}=$ $-32.1 \pm 2.7 \mathrm{cal} / \mathrm{mol} / \mathrm{K}$. At $40{ }^{\circ} \mathrm{C}, \Delta G^{*}=22.3 \pm 1.7 \mathrm{kcal} / \mathrm{mol}$. 

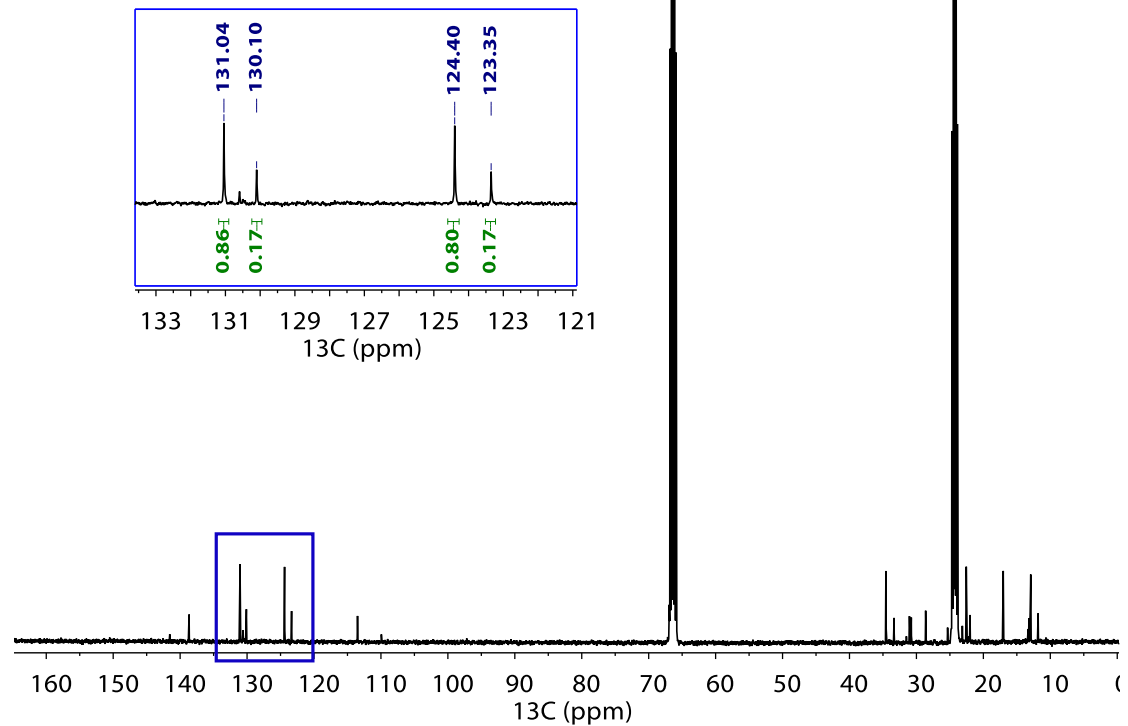

Figure S19. ${ }^{13} \mathrm{C}\left\{{ }^{1} \mathrm{H}\right\}$ NMR spectrum $\left(125 \mathrm{MHz}, 25{ }^{\circ} \mathrm{C}\right.$, THF- $\left.d_{8}\right)$ of trans- \& cis-2-hexene, in a 4:1 ratio determined by their relative integrations.

Table S1. KIE of the isomerization of 1-hexene and 1-hexene-3,3- $\mathrm{D}_{2}$ in the presence of $10 \mathrm{~mol} \%$ complex 2 in THF- $d_{8}$ at temperature range $30-60{ }^{\circ} \mathrm{C}$.

\begin{tabular}{|c|c|c|c|c|}
\hline $\mathrm{T} /{ }^{\circ} \mathrm{C}$ & 30 & 40 & 50 & 60 \\
\hline $\mathrm{k}(1$-hexene $) / \mathrm{s}^{-1}$ & $4.067 \times 10^{-5}$ & $8.633 \times 10^{-5}$ & $1.4817 \times 10^{-4}$ & $2.675 \times 10^{-4}$ \\
\hline $\mathrm{k}(1$-hexene-3,3-D 2$) / \mathrm{s}^{-1}$ & $1.52 \times 10^{-5}$ & $2.967 \times 10^{-5}$ & $5 \times 10^{-5}$ & $1.095 \times 10^{-4}$ \\
\hline KIE & 2.7 & 2.9 & 3.0 & 2.4 \\
\hline
\end{tabular}




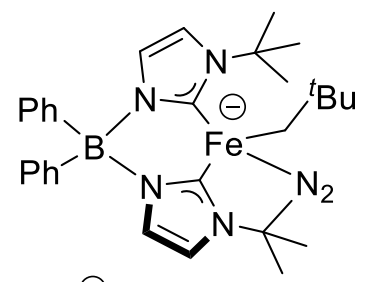

$\oplus$

K(2.2.2-cryptand)

$0.1 \mathrm{mmol}$

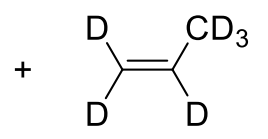

excess

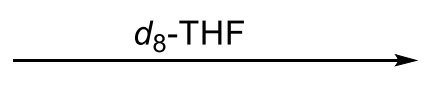

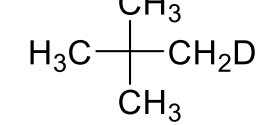

Not observed

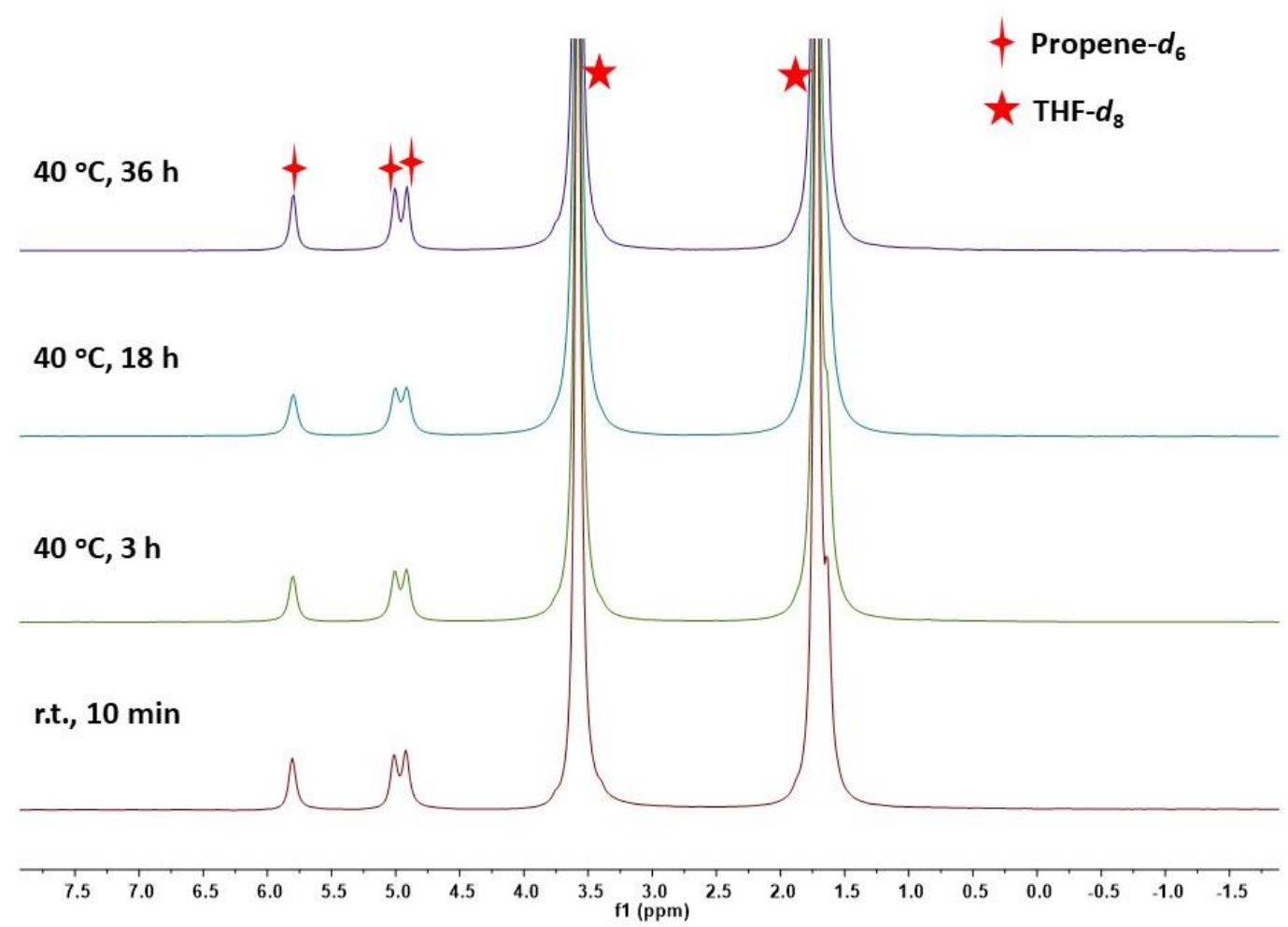

Figure S20. ${ }^{2} \mathrm{H}$ NMR of the reaction of complex $2(0.1 \mathrm{mmol})$ with propene- $d_{6}$ (excess) in THF$d_{8}$ at room temperature and $40^{\circ} \mathrm{C}$. 


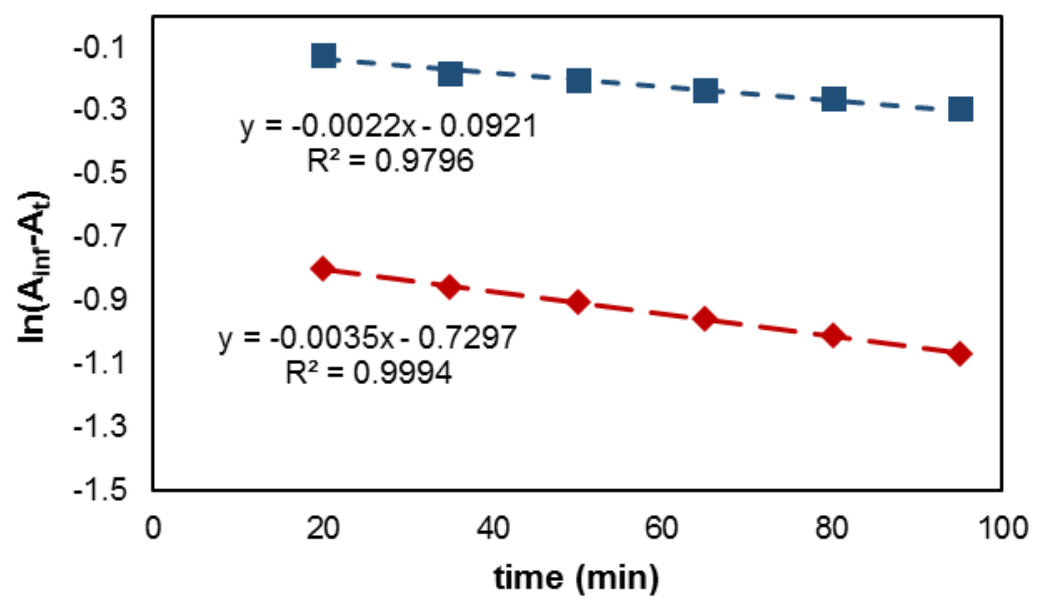

Figure S21. Increase in concentration of 2-hexene versus time, with no added DMAP (blue) and with 2 equiv. of DMAP relative to 2 (red). The first order rate constant $k_{\text {obs }}$ is essentially unchanged upon addition of DMAP. See experimental for details of experiment conditions. 
Table S2. Isomerization of 1-hexene to 2-hexene by $\mathbf{2}$ in the presence of $\mathrm{N}$-containing bases, in THF- $d_{8}$ at $40{ }^{\circ} \mathrm{C}$, after $16 \mathrm{~h}$.

\begin{tabular}{ll} 
& Computed $E_{1 / 2}(\mathrm{~V}$ \\
Vs. Fc/Fcersion ${ }^{\mathrm{b}, \mathrm{c}}$ \\
\hline
\end{tabular}

${ }^{\mathrm{a}}$ Determined by ${ }^{1} \mathrm{H}$ NMR spectroscopy with an internal standard $(\mathrm{MeCN}) ;{ }^{\mathrm{b}}$ Calculated by DFT (see Computational Details); ${ }^{\mathrm{c}}$ Computed $\mathrm{Fe}(\mathrm{II}) / \mathrm{Fe}(\mathrm{I})$ potential for $\mathrm{Ph}_{2} \mathrm{~B}\left({ }^{t} \mathrm{BuIm}\right)_{2} \mathrm{FeCH}_{2}{ }^{\mathrm{t}} \mathrm{Bu}: E_{1 / 2}$ $=-2.15 \mathrm{~V}$ vs $\mathrm{Fc}^{+} / \mathrm{Fc}$. 


\section{Equilibrium Constant Determinations}

Experimentally, complex 1 or 2 (1 mL of $2 \mathrm{mM}$ stock solution), and $1 \mathrm{~mL}$ containing the base diluted from a $200 \mathrm{mM}$ stock solution were added to a quartz cuvette. The solutions were monitored over $2 \mathrm{~h}$ as the solution equilibrated. The plot of [ $\left.\mathrm{L}_{0}\right]$ versus $\Delta \mathrm{Abs}$ was fit to Equation 1 (see main text), with refinement of $K_{\text {eq }}$ and a scaling factor, using Origin 2016 Graphing and Analysis.

The binding abilities of para-substituted pyridine ligands to complex $\mathbf{1}$ were systematically evaluated from the equilibrium constant $K_{\text {eq }}:{ }^{6}$

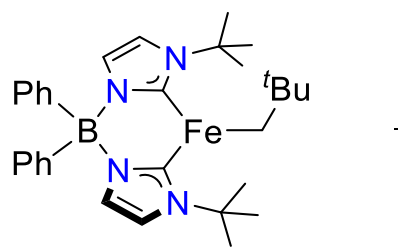<smiles>[X]c1ccncc1</smiles><smiles>[Mg][Mg]</smiles><smiles></smiles>

$$
K_{e q}=\frac{[\mathrm{Fepy}]}{[\mathrm{Fe}][\mathrm{py}]}
$$

As demonstrated for the case of pyridine, significant changes are observed in the UV-vis spectrum when the base is titrated into a solution of $\mathbf{1}$ (Figure S22a). These spectroscopic changes allow $K_{\text {eq }}$ to be determined according to the equation S1, which describes the case of weak binding between the base and 1 (Figure S22b):

$$
\frac{[\mathrm{Fepy}]}{\left[\mathrm{Fe}_{0}\right]}=\frac{K_{e q}\left[\mathrm{py}_{0}\right]}{K_{e q}\left[\mathrm{py}_{0}\right]+1}
$$


where $\left[\mathrm{Fe}_{0}\right]$ and $\left[\mathrm{py}_{0}\right]$ are the initial concentrations of $\mathbf{1}$ and the 4-substituted pyridine, respectively, while [Fepy] is the final concentration of the adduct between $\mathbf{1}$ and the pyridine.

In the case of electron-rich pyridine DMAP, tight binding is observed, as described by equation S2:

$$
[\text { Fepy }]=\frac{\left(\left[\mathrm{Fe}_{0}\right]+\left[\mathrm{py}_{0}\right]+\frac{1}{K_{\mathrm{eq}}}\right)-\left\{\left(\left[\mathrm{Fe}_{0}\right]+\left[\mathrm{py}_{0}\right]+\frac{1}{K_{\mathrm{eq}}}\right)^{2}-4\left[\mathrm{py}_{0}\right]\left[\mathrm{Fe}_{0}\right]\right\}^{1 / 2}}{2}
$$

For a series of 4-substituted pyridines, there is an excellent linear correlation between $\log K_{\text {eq }}$ and the Hammett parameter $\sigma_{\text {para }}$ (Table S3, Figure S25, $\left.\rho=-2.0\right),{ }^{7}$ as would be intuitively expected for the binding of a $\sigma$-donor base to a Lewis acidic transition metal center. It is notable that the binding of these pyridines to $\mathbf{1}$ is many orders of magnitude weaker than for three-coordinate iron(II) $\beta$-diketiminate complexes. ${ }^{8}$ Steric effects are unlikely to be responsible for these differences as the slim acetonitrile ligand shows little propensity to bind to $\mathbf{1}$, in contrast to the $\beta$ diketiminate complexes. ${ }^{8}$ 

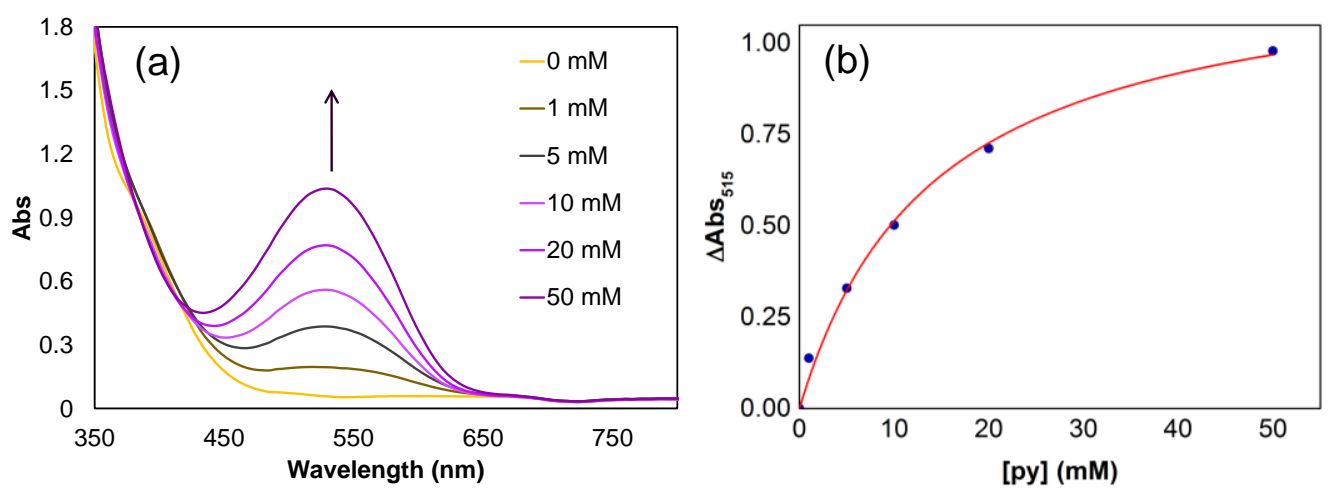

Figure S22. (a) Titration of 1 (1 mM) with pyridine (up to $50 \mathrm{mM}$ ) in toluene; (b) binding curve giving $K_{\mathrm{eq}}=0.07 \pm 0.01 \mathrm{M}^{-1}$
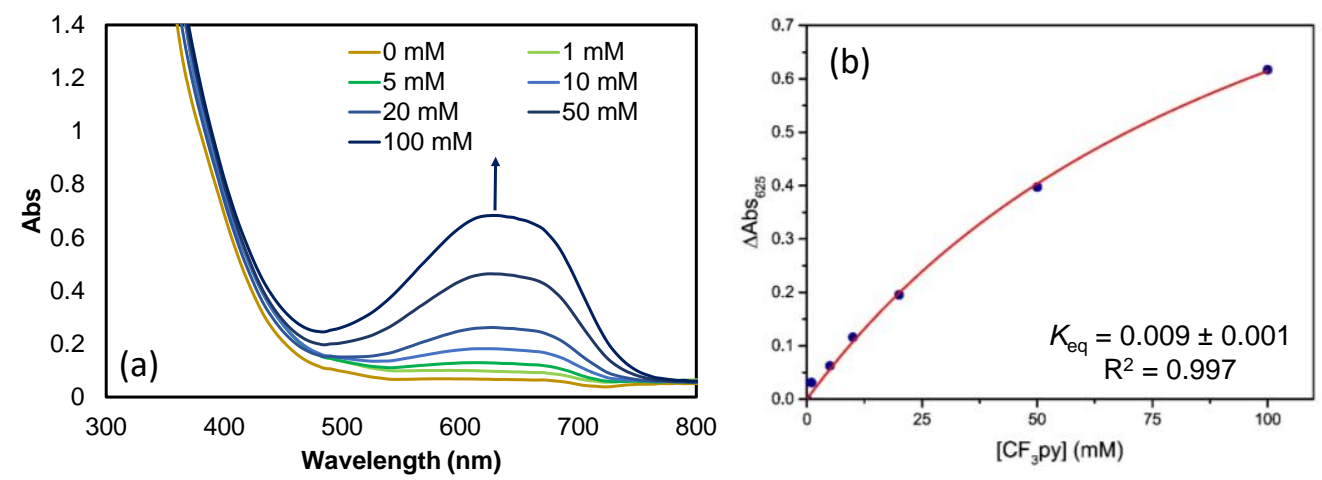

Figure S23. (a) Titration of $1(1 \mathrm{mM})$ with 4-CF - -pyridine (up to $100 \mathrm{mM}$ ) in toluene; (b) binding curve giving $K_{\mathrm{eq}}=0.009 \pm 0.001 \mathrm{M}^{-1}$. 

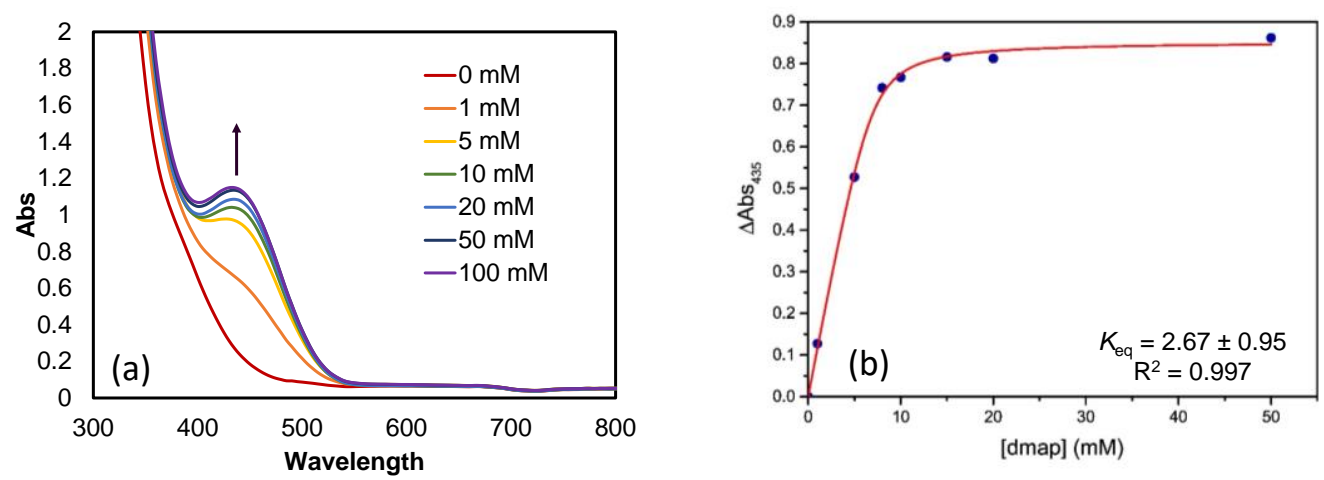

Figure S24. (a) Titration of 1 (1 mM) with DMAP (up to $100 \mathrm{mM}$ ) in toluene; (b) binding curve giving $K_{\mathrm{eq}}=2.67 \pm 0.95 \mathrm{M}^{-1}$.

Table S3. Calculated equilibrium constants of base to complex $\mathbf{1}$ in toluene.

\begin{tabular}{lll}
\hline 4-Substituent & $\sigma_{\text {para }}$ & $K_{\text {eq }}\left(\mathrm{M}^{-1}\right)$ \\
\hline $\mathrm{NMe}_{2}$ & -0.83 & $2.67 \pm 0.95$ \\
$\mathrm{H}$ & 0 & $0.07 \pm 0.01$ \\
$\mathrm{CF}_{3}$ & 0.53 & $0.009 \pm 0.001$ \\
\hline
\end{tabular}




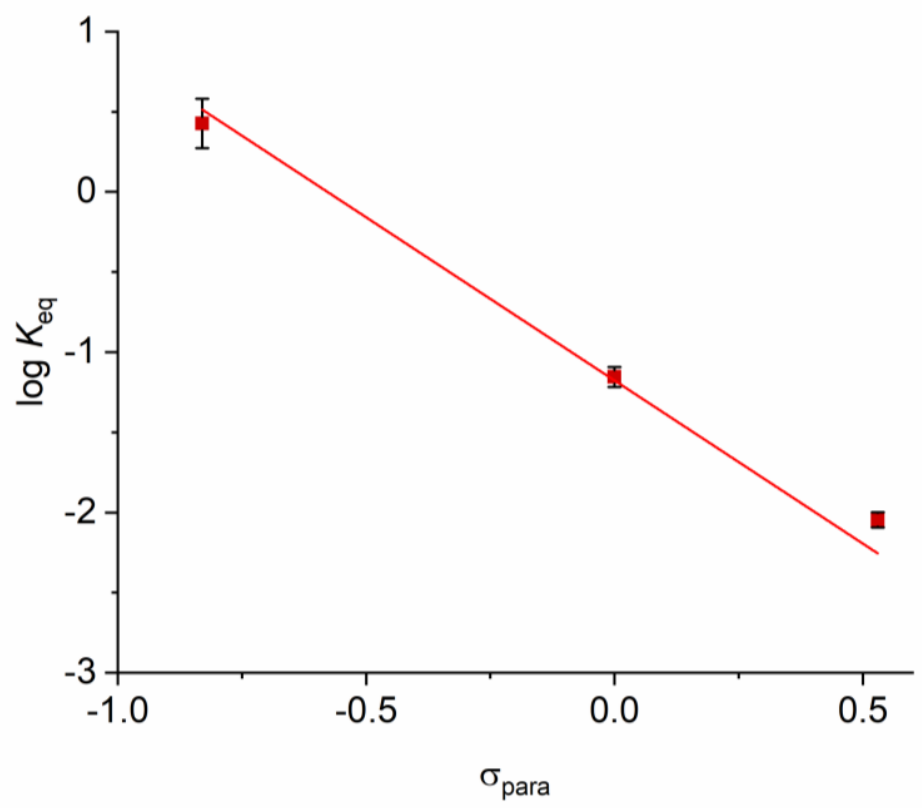

Figure S25. Hammett plot for binding of 4-substituted pyridines to $\mathbf{1}$. Linear least squares fitting gives $\rho=-2.0\left(\mathrm{R}^{2}=0.966\right)$.

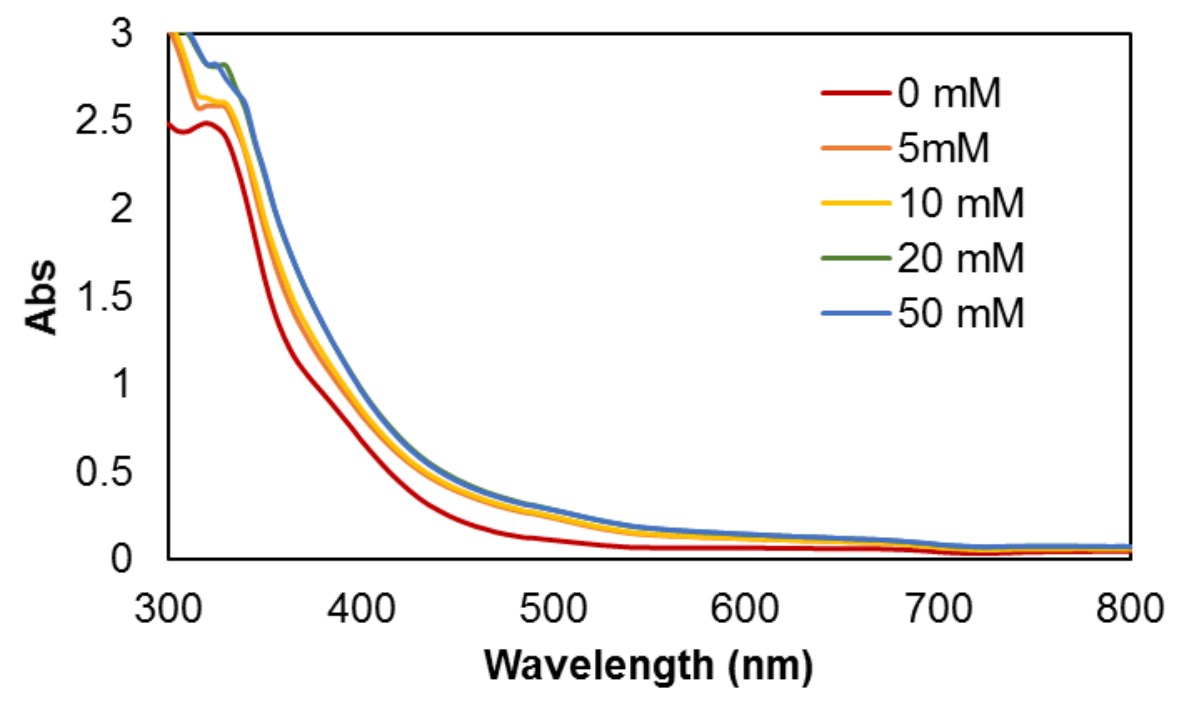

Figure S26. (a) Titration of $\mathbf{1}(1 \mathrm{mM}$ ) with $\mathrm{MeCN}$ (up to $50 \mathrm{mM}$ ) in toluene. 
In the case of $\mathbf{2}$, equilibrium constants were determined for the reaction:

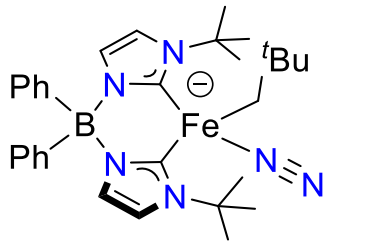<smiles>[X]c1ccncc1</smiles>

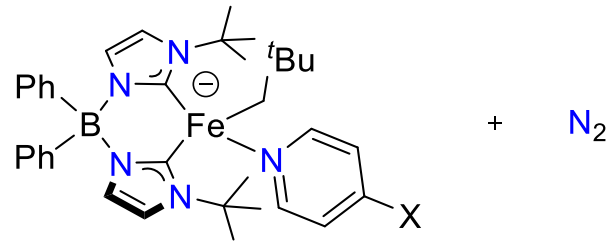

$$
K_{e q}=\frac{[\mathrm{Fepy}]\left[\mathrm{N}_{2}\right]}{\left[\mathrm{FeN}_{2}\right][\mathrm{py}]}
$$

The concentration of iron pyridine adduct at equilibrium is given by:

$$
[\text { Fepy }]=\left[\mathrm{FeN}_{2}\right]_{0}-\left[\mathrm{FeN}_{2}\right]_{\mathrm{f}}
$$

where $\left[\mathrm{FeN}_{2}\right]_{0}$ is the initial concentration of iron complex and $\left[\mathrm{FeN}_{2}\right]_{\mathrm{f}}$ is the concentration at equilibrium.

Substituting into the equilibrium constant expression:

$$
K_{e q}=\frac{[\mathrm{Fepy}]\left[\mathrm{N}_{2}\right]}{\left(\left[\mathrm{FeN}_{2}\right]_{0}-[\mathrm{Fepy}]\right)[\mathrm{py}]}
$$

Solving for $[\mathrm{Fepy}] /\left[\mathrm{FeN}_{2}\right]_{0}$ gives:

$$
\frac{[\text { Fepy }]}{\left[\mathrm{FeN}_{2}\right]_{0}}=\frac{K_{e q}[\mathrm{py}]_{0}}{K_{e q}[\mathrm{py}]_{0}+\left[\mathrm{N}_{2}\right]}
$$

where [py $]_{0}$ is the initial concentration of added pyridine. This expression will be valid for "weak binding" conditions, where the change in pyridine concentration is small. 
We note that $K_{\text {eq }}$ will be perturbed by the equilibrium between dissolved and gas-phase $\mathrm{N}_{2}$. The final concentration of $\mathrm{N}_{2}$ is determined by the solubility of $\mathrm{N}_{2}$ in THF, $\left[\mathrm{N}_{2}\right]=6.4 \times 10^{-3} \mathrm{M}$ at 298 K. ${ }^{9}$ Test calculations reveal that $K_{\text {eq }}$ is not very sensitive to the value of $\left[\mathrm{N}_{2}\right]$. To ensure that $\left[\mathrm{N}_{2}\right]$ was at the equilibrium concentration, all solutions were equilibrated for $24 \mathrm{~h}$ before measurement.
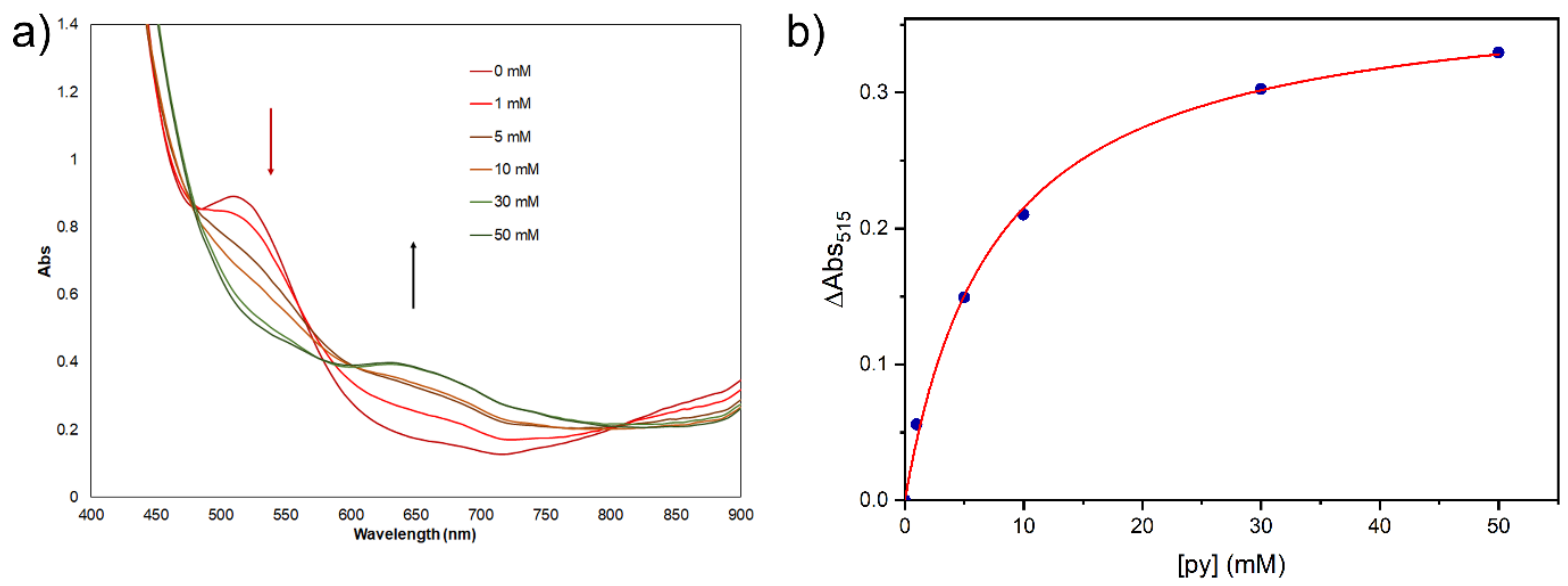

Figure S27. (a) Titration of complex 2 (1 mmol) with pyridine (up to $50 \mathrm{mM}$ ) in THF; (b) Binding curve giving $K_{\mathrm{eq}}=0.13 \pm 0.01\left(\mathrm{R}^{2}=0.997\right)$.
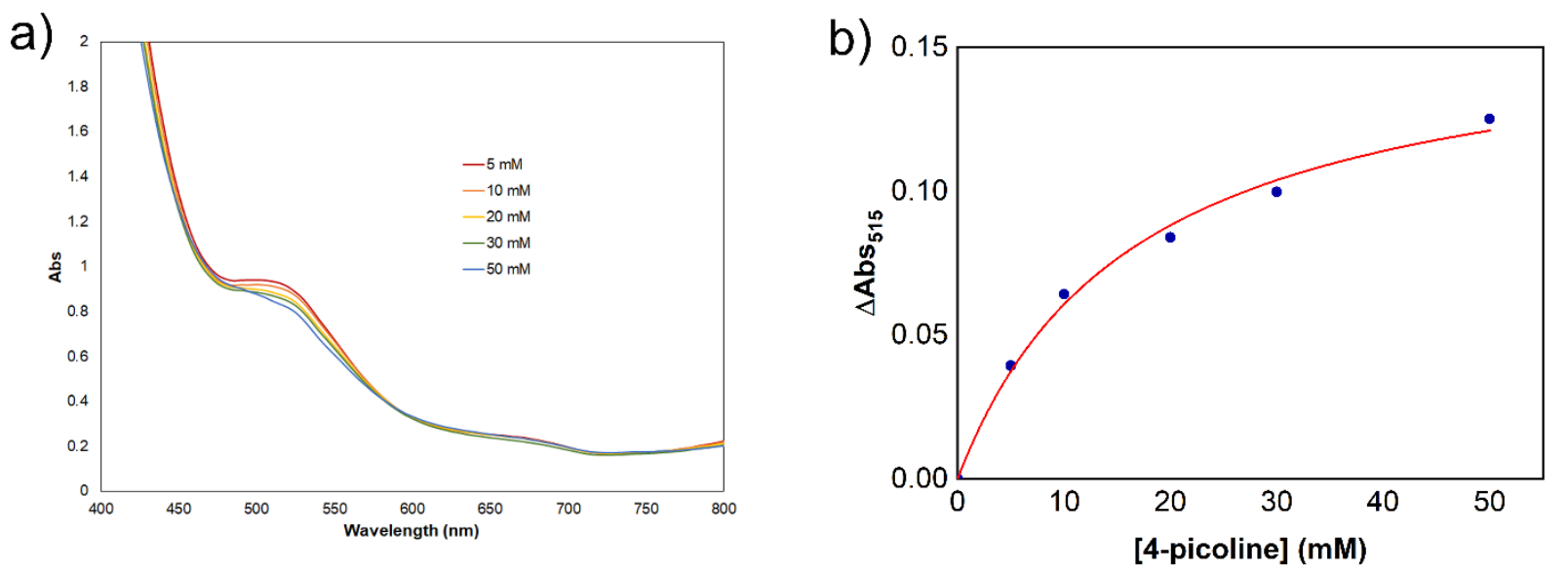

Figure S28. (a) Titration of $2(1 \mathrm{mM})$ with 4-picoline (up to $50 \mathrm{mM}$ ) in THF; (b) binding curve giving $K_{\mathrm{eq}}=0.060 \pm 0.009$. 
a)

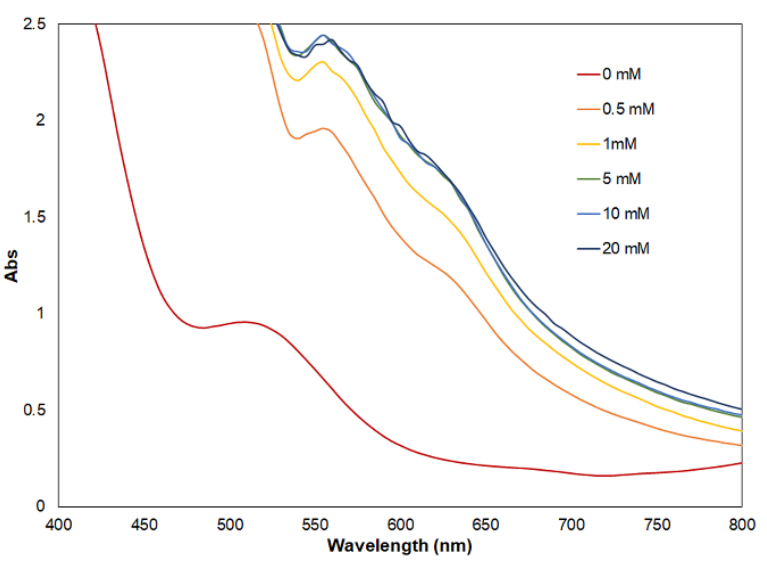

b)

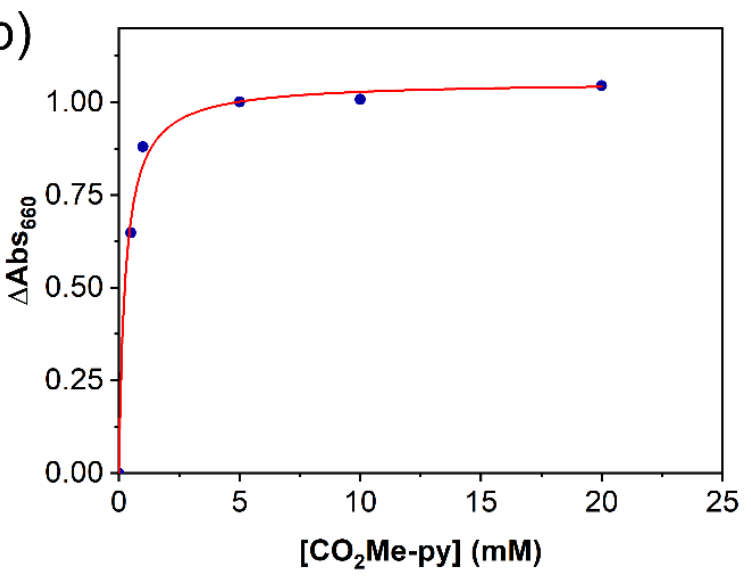

Figure S29. (a) Titration of $2(1 \mathrm{mM})$ with 4- $\mathrm{CO}_{2} \mathrm{Me}-$ pyridine (up to $20 \mathrm{mM}$ ) in THF; (b) binding curve giving $K_{\mathrm{eq}}=3.6 \pm 0.5\left(\mathrm{R}^{2}=0.993\right)$.

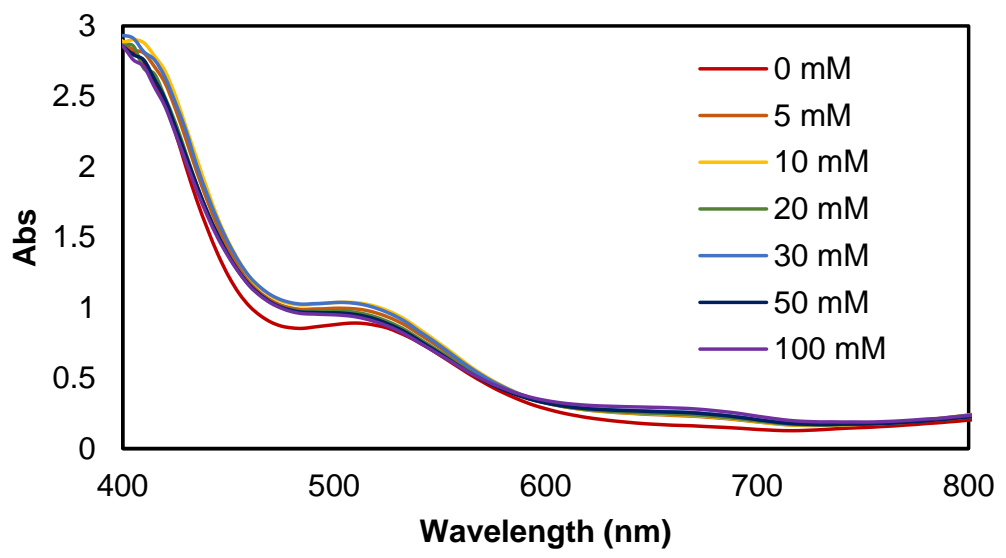

Figure S30. Titration of complex 2 with DMAP (up to $100 \mathrm{mM}$ ). No isosbestic point is observed, and binding of DMAP is inferred to be very small $\left(K_{\mathrm{eq}} \ll<\mathrm{M}^{-1}\right)$. Small deviations are attributed to thermal decomposition of $\mathbf{2}$ during equilibration. 
Table S4. Experimentally determined equilibrium constants for binding of base to complex 2 in THF.

\begin{tabular}{lll}
\hline 4-Substituent & $\sigma_{\mathrm{p}}{ }^{-}$ & $K_{\mathrm{eq}}$ \\
\hline $\mathrm{Me}$ & -0.17 & $(3.9 \pm 0.5) \times 10^{-4}$ \\
$\mathrm{H}$ & 0 & $(5.3 \pm 0.9) \times 10^{-4}$ \\
$\mathrm{CO}_{2} \mathrm{Me}$ & 0.64 & $0.022 \pm 0.003$ \\
\hline
\end{tabular}
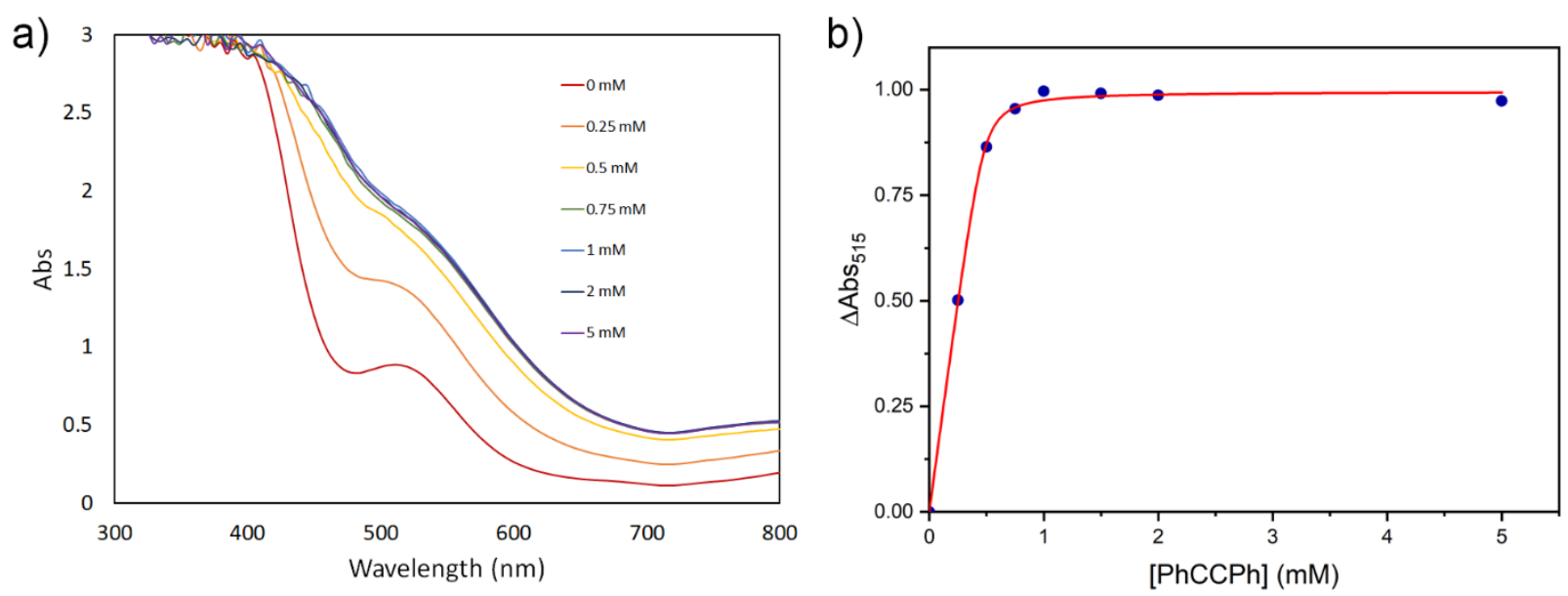

Figure S31. (a) Titration of 2 (1 mM) with diphenylacetylene (up to $5 \mathrm{mM}$ ) in THF; (b) binding curve giving $K_{\mathrm{eq}}=87 \pm 31 \mathrm{M}^{-1}, \Delta G=-2.6 \pm 0.3 \mathrm{kcal} / \mathrm{mol}$ at $298 \mathrm{~K}$. 


\section{Computational Details}

All calculations were performed using density functional theory as implemented in the Orca 3.0.3 computational software package. ${ }^{10}$ Geometry optimizations for all complexes were performed with the B3LYP functional, and def2-SVP ${ }^{11}$ basis sets. Reevaluation of the electronic energies (single point energy corrections) was done with a hybrid triple/double zeta basis set ma-def2TZVP/SVP. The Fe center, all atoms attached to Fe and/or conjugated with Fe (carbene ligands), and the entire butene ligand was treated with the ma-def2-TZVP basis set for mathematically flexibility. All other atoms were treated with the smaller ma-def2-SVP basis set. Additionally, the Fe center was treated with the $\mathrm{DKH} 2$ effective core potential to increase computational efficiency. Vibrational/rotational/translational entropies of the solute(s) were included using standard thermodynamic approximations. Solvation energies were determined by a self-consistent reaction field (SCRF) approach. Solvation calculations were carried out on optimized gas phase geometries employing the dielectric constant of $\varepsilon=7.25$ (THF) and a refractive index of 1.407 . The standard set of optimized radii were used to generate the solute surface. All structures were verified to be minima on the potential energy surface by the removal of imaginary frequencies. Determination of the change in solution phase free energy $\Delta G_{(\mathrm{sol})}$ was calculated as follows:

$$
\begin{aligned}
& \Delta G_{(\mathrm{sol})}=\Delta G_{(\mathrm{gas})}+\Delta \Delta G_{\mathrm{solv}} \\
& \Delta G_{(\mathrm{gas})}=\Delta H_{(\mathrm{gas})}-T \Delta S_{(\mathrm{gas})} \\
& \Delta H_{(\mathrm{gas})}=\Delta E_{(\mathrm{scf})}+\Delta \mathrm{ZPE} \\
& \Delta G_{(\mathrm{sol})}^{\mathrm{EA}}=-\mathrm{nF} E_{1 / 2}
\end{aligned}
$$


where $\Delta G_{\text {(gas) }}=$ change in gas phase free energy; $\Delta \Delta G_{\text {solv }}=$ change in free energy of solvation; $\Delta H_{\text {(gas) }}=$ change in gas phase enthalpy; $\mathrm{T}=$ temperature $(298.15 \mathrm{~K}) ; \Delta S_{(\mathrm{gas})}=$ change in gas phase entropy; $\Delta E_{\text {(scf) }}=$ self-consistent field energy or the electronic energy at the triple- $\zeta$ level; $\Delta \mathrm{ZPE}$ $=$ change in vibrational zero point energy, $\Delta G^{\mathrm{EA}}$ (sol) $=$ electron attachment free energy in the gas phase, $\mathrm{F}=$ Faraday's constant, $\mathrm{n}=$ number of electrons, and $E_{1 / 2}$ is the redox potential. The computed redox potentials were converted to absolute energy terms by subtracting $4.28 \mathrm{~V}$ vs. NHE. The true value of the NHE potential ranges from 4.28 to $4.43 \mathrm{~V}$. By assuming a value of $4.28 \mathrm{~V}$, there is a systematic error in the computed redox potentials of up to $150 \mathrm{mV} .^{12}$

The reaction of $\mathbf{2}$ with diphenylacetylene was chosen for a DFT functional dependence study that experimentally calibrates the computational investigation. Multiple functionals were tested (Table S5). Such a large test set was used because of the considerable difficultly in matching the experimental thermodynamics. Diffuse functions were found to be essential for replicating experimental data. In general, including HF exchange drastically overestimated the driving force for the reaction, while pure functionals produced better results. PBE-D3BJ provided the closest match to the experimental results and was therefore chosen for the complete isomerization mechanism analysis. The calculated barrier height with the PBE-D3BJ functional also provided a good match $(26.5 \mathrm{kcal} / \mathrm{mol})$ to the experimentally calculated barrier height of $21.0 \mathrm{kcal} / \mathrm{mol}$.
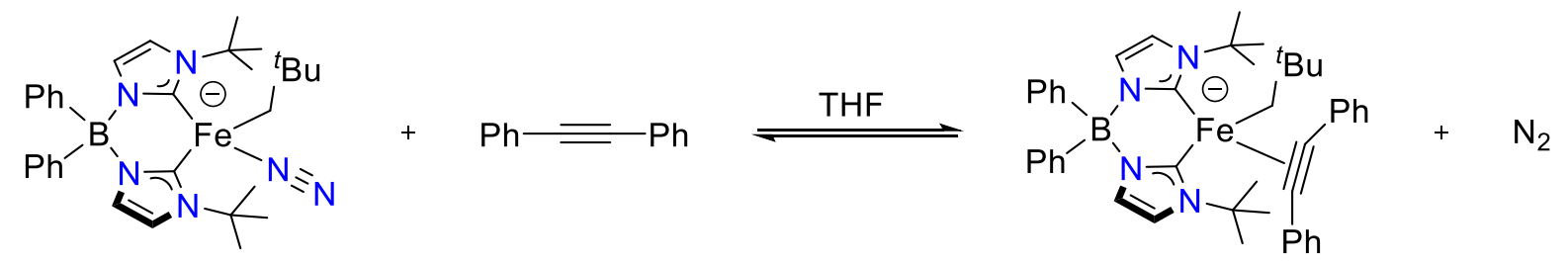
Table S5. Functional dependence study for the reaction between 2 and $\mathrm{PhCCPh}$ at the ma-def2TZVP/SVP level of theory.

\begin{tabular}{|c|c|c|c|}
\hline Functional & $\Delta G_{\mathrm{sol}}(\mathrm{kcal} / \mathrm{mol})$ & Functional & $\Delta G_{\mathrm{sol}}(\mathrm{kcal} / \mathrm{mol})$ \\
\hline M06 & -17.25 & PBE-D3BJ & -5.31 \\
\hline M06L & -10.77 & PBE0-D3BJ & -21.27 \\
\hline BLYP-D3BJ & -10.32 & BP86-D3BJ & -16.37 \\
\hline B3LYP-D3BJ & -16.86 & B97-D3BJ & -11.61 \\
\hline TPSS & -12.80 & $\omega B 97-D 3 B J$ & -18.28 \\
\hline \multicolumn{2}{|c|}{ Experimental value } & \multicolumn{2}{|c|}{$-2.6 \pm 0.3 \mathrm{kcal} / \mathrm{mol}$} \\
\hline
\end{tabular}




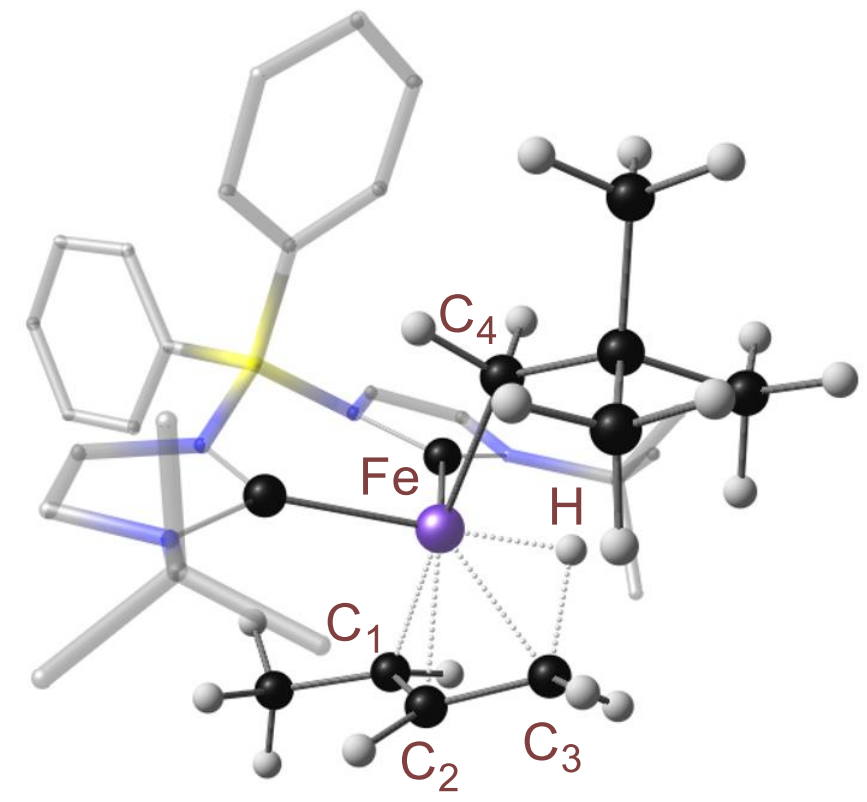

Figure S32. Representation of transition state ${ }^{2} \mathbf{T S 2}$ showing the " $\eta^{3}$-allyl like" nature of the optimized complex and is analogous to ${ }^{2}$ TS1. Selected bond lengths $(\AA)$ : Fe-H 1.527; Fe-C 1 2.167; $\mathrm{Fe}-\mathrm{C}_{2}$ 1.990; Fe-C $\mathrm{C}_{3} 2.076 ; \mathrm{Fe}-\mathrm{C}_{4} 2.109 ; \mathrm{C}_{1}-\mathrm{C}_{2} 1.415 ; \mathrm{C}_{2}-\mathrm{C}_{3} 1.444 ; \mathrm{C}_{3}-\mathrm{H} 1.534$. 


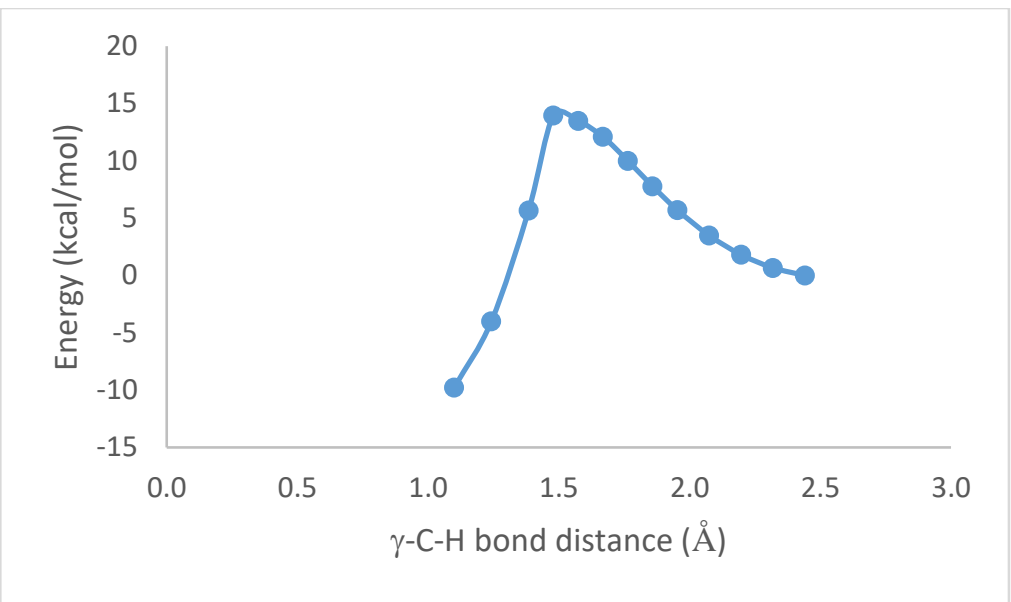

Figure S33. LST (B3LYP def2-SVP) analysis for reductive elimination of the $\gamma-\mathrm{C}-\mathrm{H}$ bond of the isomerized $\eta^{2}$-alkene ligand from ${ }^{4} \mathbf{C}$ on the low spin surface.

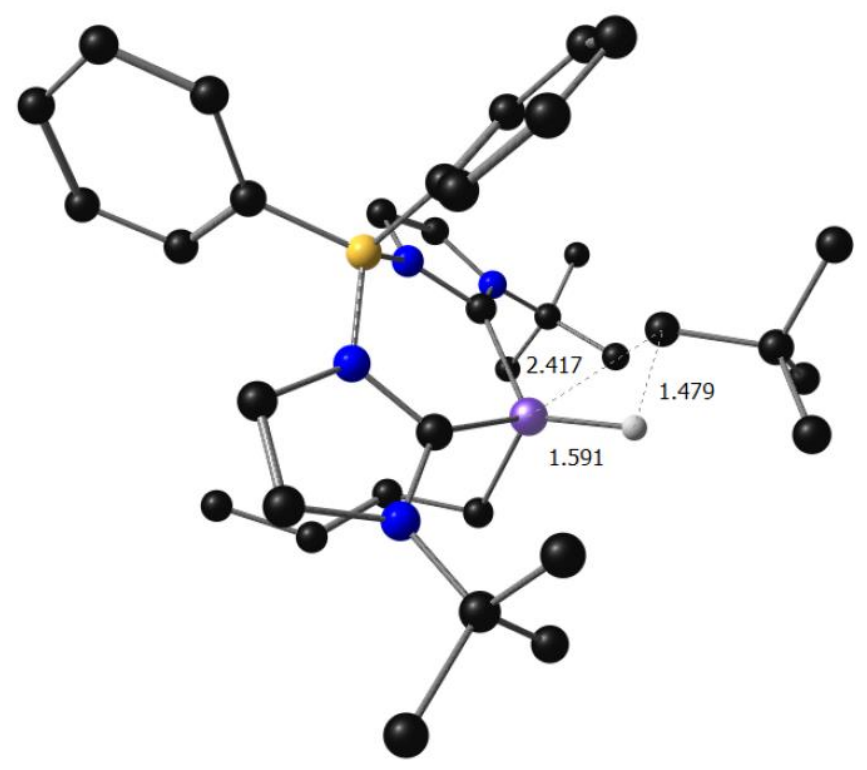

Figure S34. Representation of the LST highest energy structure for neopentane reductive elimination. Selected bond lengths: Fe-neopentyl carbon $=2.417 \AA$, neopentyl carbon-H $=1.479$ $\AA$, and Fe-H $=1.591 \AA$. Reevaluation of the single point energy with the ma-def2-TZVP/SVP PBE D3BJ basis set provided an energy of $28.75 \mathrm{kcal} / \mathrm{mol}$ uphill from 2. 

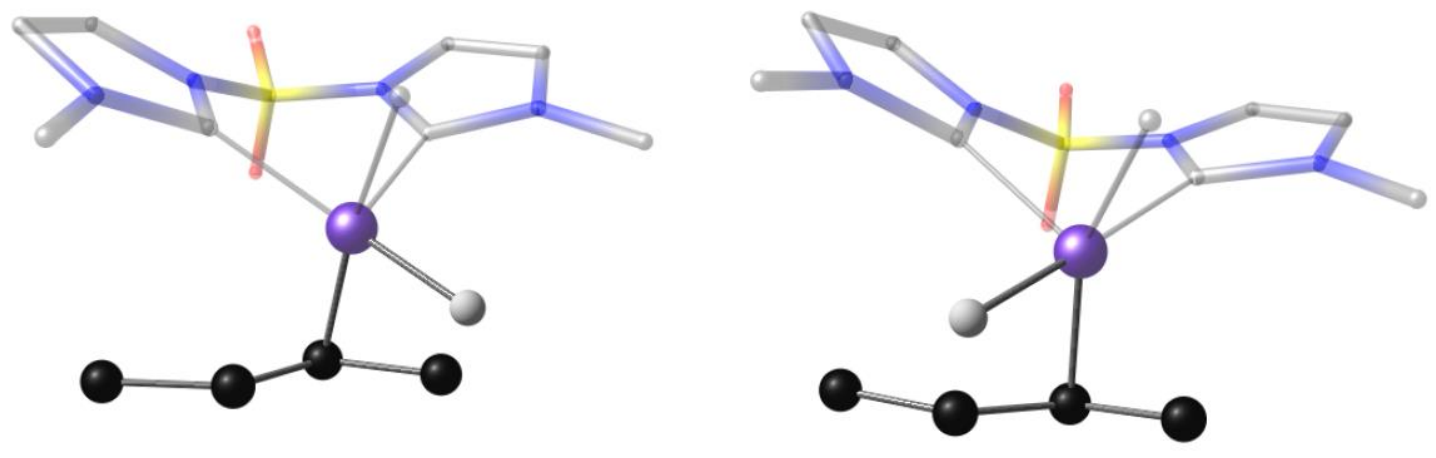

Figure S35. Optimized transition state for the model compound for oxidative addition and reductive elimination. All R-groups on the NHC donors as well as the neopentyl ligand were truncated to methyl groups. Imaginary frequency $=-605 \mathrm{~cm}^{-1}$.

Using a model complex (Figure S35) transition states both oxidative addition and reductive elimination on the low spin surface could be optimized. However, due to the loss of steric bulk from the ligands, the allyl ligand rotated relative to the bis(carbene) borate ligand. This orientation of the allyl ligand is not representative of the full complex but was still successful in optimizing the transition state on the low spin surface for the full complex. Attempts to optimize this type of transition state as a starting guess for the concerted 1-3 hydride shift mechanism were unsuccessful. 


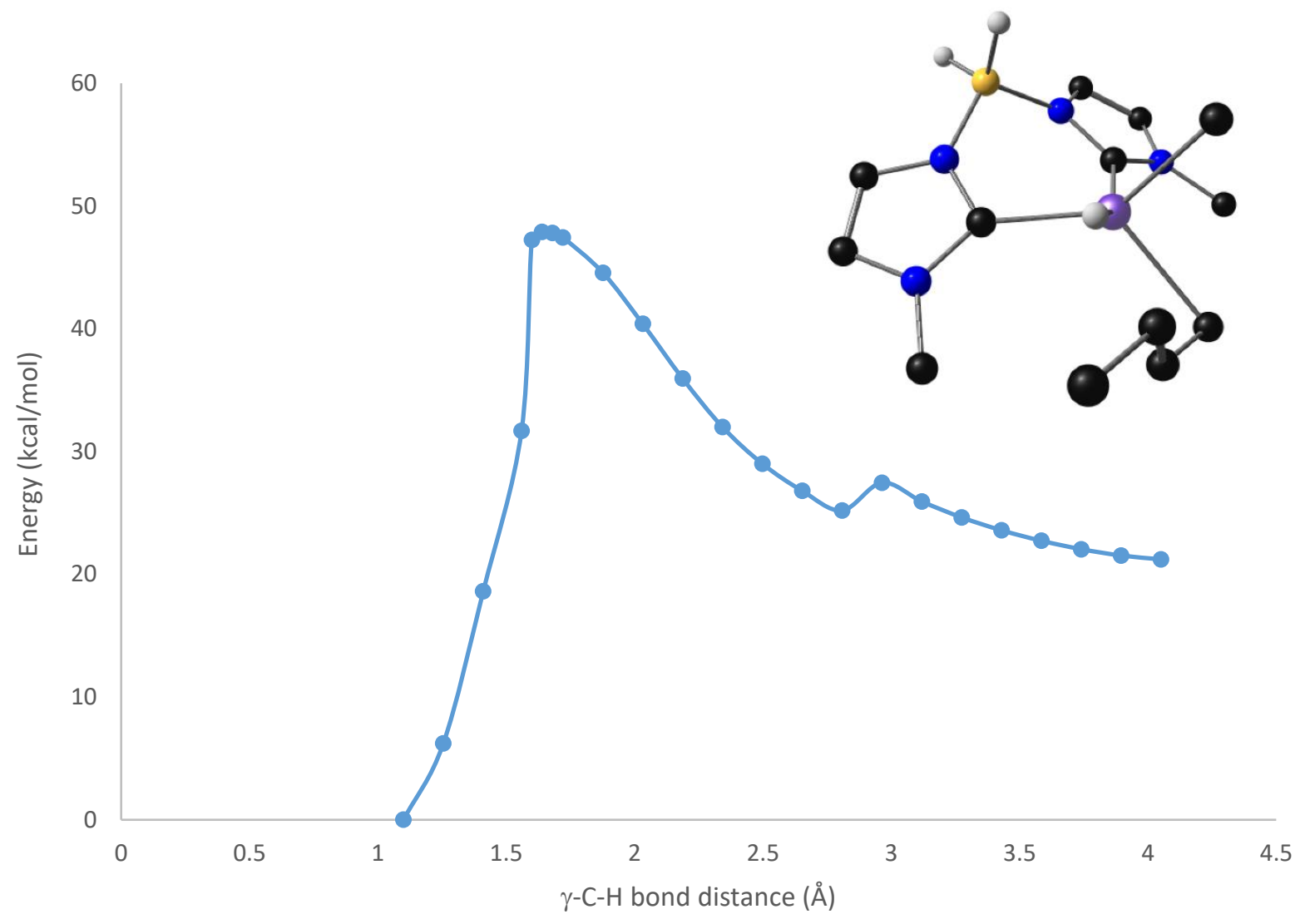

Figure S36. LST analysis the energy surface for oxidative addition on the high spin surface. The energy reaches a maximum at $c a .1 .5 \AA$, however no transition state could be optimized through a quadratic synchronous transit (QST). 


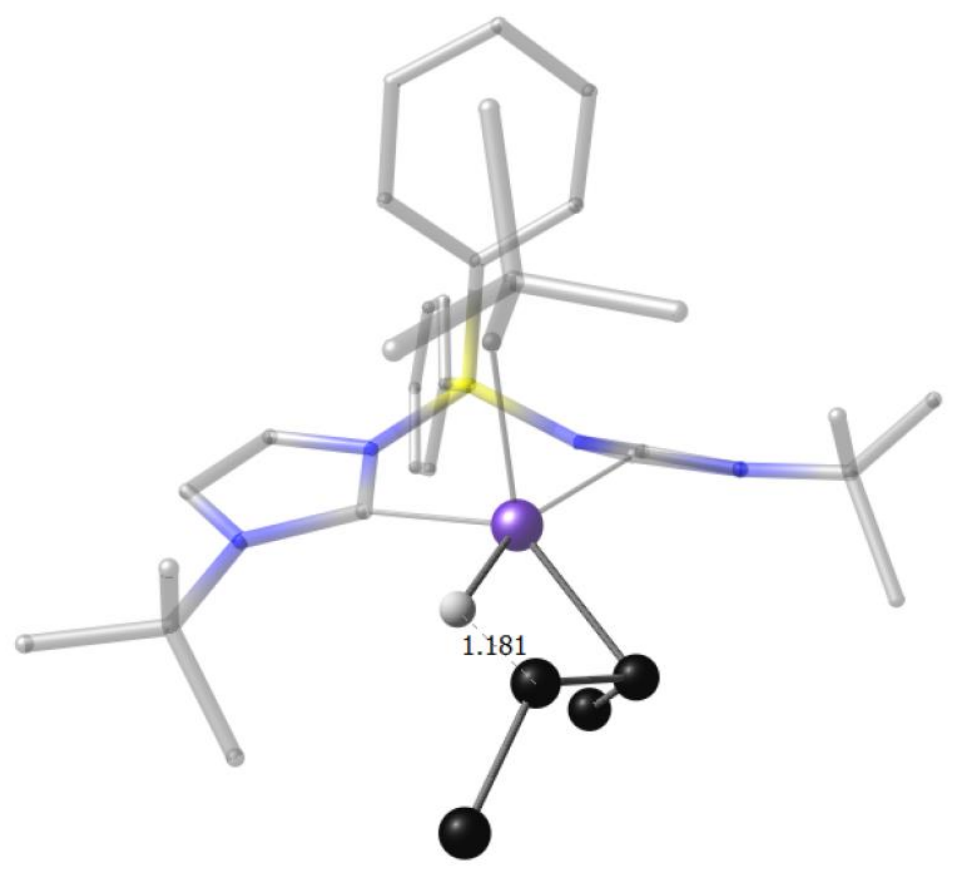

Figure S37. Structure of the highest energy structure on the high spin $(S=3 / 2)$ surface. From LST analysis (below).

LST analysis of the high spin transition state for oxidative addition reveals a high energy maximum (+ $45 \mathrm{kcal} / \mathrm{mol}$ uphill). The $\gamma-\mathrm{C}-\mathrm{H}$ bond of the $\eta^{2}$-alkene ligand in ${ }^{4} \mathbf{A}$ shows very little $\mathrm{C}-\mathrm{H}$ activation (Figure S37). Due to the low symmetry of the complex, QST analysis failed to converge to an optimized structure.

Due to the symmetric nature of the oxidative addition and reductive elimination transition state, attempts were made to find the reductive elimination transition state from the same structure by changing the position of the methyl group on the $\eta^{2}$-alkene from the syn to the anti position. No 
optimized transition states could be found on the high spin surface for either oxidative addition or reductive elimination.

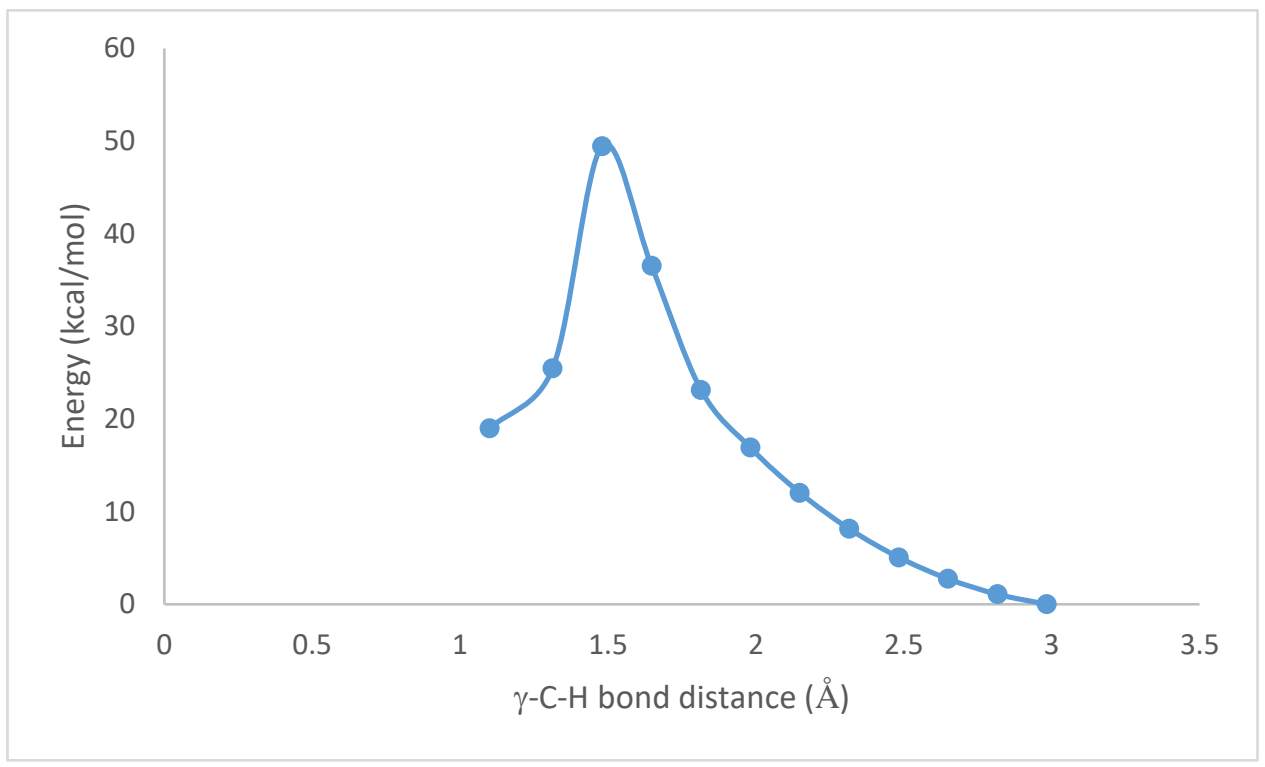

Figure S38. LST analysis for oxidative addition of the $\gamma-\mathrm{C}-\mathrm{H}$ bond of the $\eta^{2}$-alkene ligand in ${ }^{4} \mathbf{A}$. Highest energy structure shown in Figure S37. 


\section{Crystallographic Data Collection}

General Considerations. Crystals were evaluated using a Bruker Apex Kappa Duo diffractometer using Mo K $\alpha$ radiation $(0.71073 \AA$ ) at $150 \mathrm{~K}$. Final cell constants were calculated from the xyz centroids of the strong reflections from the actual data collection after integration (SAINT). ${ }^{13}$ The intensity data were corrected for absorption (SADABS). ${ }^{14}$ Structures were solved using SIR-92 and refined (full-matrix-least squares) using the Oxford University Crystals for Windows system. ${ }^{15}$ Goodness-of-fit $\left.=\left[\Sigma\left[w\left(\mathrm{~F}_{\mathrm{o}}^{2}-\mathrm{F}_{\mathrm{c}}^{2}\right)^{2}\right] / \mathrm{N}_{\text {observns }}-\mathrm{N}_{\text {params }}\right)\right]^{1 / 2}$, all data. $\mathrm{R} 1=\Sigma\left(\left|\mathrm{F}_{\mathrm{o}}\right|-\left|\mathrm{F}_{\mathrm{c}}\right|\right) / \Sigma\left|\mathrm{F}_{\mathrm{o}}\right| . \quad w \mathrm{R} 2$ $=\left[\Sigma\left[w\left(\mathrm{~F}_{\mathrm{o}}^{2}-\mathrm{F}_{\mathrm{c}}{ }^{2}\right)^{2}\right] / \Sigma\left[w\left(\mathrm{~F}_{\mathrm{o}}^{2}\right)^{2}\right]\right]^{1 / 2}$. 


\section{$\mathrm{Ph}_{2} \mathrm{~B}\left({ }^{\mathrm{t}} \mathrm{BuIm}\right)_{2} \mathrm{FeCH}_{2}{ }^{\mathrm{t}} \mathrm{Bu}(\mathbf{1})$}

Empirical formula

Formula weight

Crystal color, shape, size

Temperature

Wavelength

Crystal system, space group

Unit cell dimensions

Volume

$\mathrm{Z}$

Density (calculated)

Absorption coefficient

$\mathrm{F}(000)$

Data collection

Diffractometer

Theta range for data collection

Index ranges

Reflections collected

Independent reflections

Observed Reflections

Completeness to theta $=27.084^{\circ}$

Solution and Refinement

Absorption correction

Max. and min. transmission

Solution

Refinement method

Weighting scheme

Data / restraints / parameters

Goodness-of-fit on $\mathrm{F}^{2}$

Final $\mathrm{R}$ indices [I>2sigma(I)]

$\mathrm{R}$ indices (all data)

Largest diff. peak and hole
C31 H43 B1 Fe1 N4

538.37

yellow block, $0.200 \times 0.150 \times 0.150 \mathrm{~mm}^{3}$

$150 \mathrm{~K}$

$0.71073 \AA$

Triclinic, P-1

$\mathrm{a}=10.8599(7) \AA$

$\mathrm{b}=15.6364(10) \AA$

$\mathrm{c}=18.5091(12) \AA$

3029.7(2) $\AA^{3}$

4

$1.180 \mathrm{Mg} / \mathrm{m}^{3}$

$0.523 \mathrm{~mm}^{-1}$

1152

Bruker Apex Kappa Duo, Bruker

1.141 to $27.637^{\circ}$.

$-14<=\mathrm{h}<=14,-20<=\mathrm{k}<=20,-24<=\mathrm{l}<=24$

47700

$14045[\mathrm{R}(\mathrm{int})=0.033]$

12980

$99.8 \%$

Semi-empirical from equivalents

0.92 and 0.92

Direct methods

Full-matrix least-squares on $\mathrm{F}^{2}$

$\mathrm{w}=\left[\sigma^{2} \mathrm{Fo}^{2}+\mathrm{AP}^{2}+\mathrm{BP}\right]^{2}$, with

$\mathrm{P}=\left(\mathrm{Fo}^{2}+2 \mathrm{Fc}^{2}\right) / 3, \mathrm{~A}=0.039, \mathrm{~B}=1.615$

13982 / 18 / 695

1.0214

$\mathrm{R} 1=0.0354, \mathrm{wR} 2=0.0874$

$\mathrm{R} 1=0.0387, \mathrm{wR} 2=0.0925$

0.58 and -0.38 e. $\AA^{-3}$ $\alpha=82.007(2)^{\circ}$.

$\beta=76.765(2)^{\circ}$.

$\gamma=88.675(2)^{\circ}$. 


\section{$[\mathrm{K}(2.2 .2$-cryptand $)]\left[\mathrm{Ph}_{2} \mathrm{~B}\left({ }^{\mathrm{t}} \mathrm{BuIm}\right)_{2} \mathrm{FeCH}_{2}{ }^{\mathrm{t}} \mathrm{Bu}\left(\mathrm{N}_{2}\right)\right](2)$}

Empirical formula

Formula weight

Crystal color, shape, size

Temperature

Wavelength

Crystal system, space group

Unit cell dimensions

Volume

Z

Density (calculated)

Absorption coefficient

$\mathrm{F}(000)$

Data collection

Diffractometer

Theta range for data collection

Index ranges

Reflections collected

Independent reflections

Observed Reflections

Completeness to theta $=25.246^{\circ}$

Solution and Refinement

Absorption correction

Max. and min. transmission

Solution

Refinement method

Weighting scheme

Data / restraints / parameters

Goodness-of-fit on $\mathrm{F}^{2}$

Final $\mathrm{R}$ indices [I $>2 \operatorname{sigma}(\mathrm{I})]$

$\mathrm{R}$ indices (all data)

Largest diff. peak and hole
C57 H95 B1 Fe1 K1 N8 O8

1126.19

red block, $0.200 \times 0.200 \times 0.100 \mathrm{~mm}^{3}$

$150 \mathrm{~K}$

$0.71073 \AA$

Monoclinic, $\mathrm{P} 21 / \mathrm{n}$

$\mathrm{a}=14.3841(15) \AA$

$\mathrm{b}=27.175(3) \AA$

$\mathrm{c}=16.4900(16) \AA$

6442.8(6) $\AA^{3}$

4

$1.161 \mathrm{Mg} / \mathrm{m}^{3}$

$0.353 \mathrm{~mm}^{-1}$

2428

Bruker Apex Kappa Duo, Bruker

1.445 to $25.246^{\circ}$.

$-17<=\mathrm{h}<=17,0<=\mathrm{k}<=32,0<=\mathrm{l}<=19$

11294

$11294[\mathrm{R}(\mathrm{int})=0.061]$

7439

$96.8 \%$

Semi-empirical from equivalents

0.97 and 0.93

Direct methods

Full-matrix least-squares on $\mathrm{F}^{2}$

$\mathrm{w}=\left[\sigma^{2} \mathrm{Fo}^{2}+\mathrm{AP}^{2}+\mathrm{BP}\right]^{-1}$, with

$\mathrm{P}=\left(\mathrm{Fo}^{2}+2 \mathrm{Fc}^{2}\right) / 3, \mathrm{~A}=0.065, \mathrm{~B}=26.560$

11241 / 94 / 673

0.9777

$\mathrm{R} 1=0.0700, \mathrm{wR} 2=0.1869$

$\mathrm{R} 1=0.1017, \mathrm{wR} 2=0.2013$

0.88 and -0.70 e. $\AA^{-3}$ $\alpha=90^{\circ}$.

$\beta=91.727(4)^{\circ}$.

$\gamma=90^{\circ}$. 


\section{$[\mathrm{K}(2.2 .2$-cryptand $)]\left[\mathrm{Ph}_{2} \mathrm{~B}\left({ }^{\mathrm{t}} \mathrm{BuIm}\right){ }_{2} \mathrm{FeCH}_{2}{ }^{\mathrm{t}} \mathrm{Bu}\left(\eta^{2}-\mathrm{PhCCPh}\right)\right](3)$}

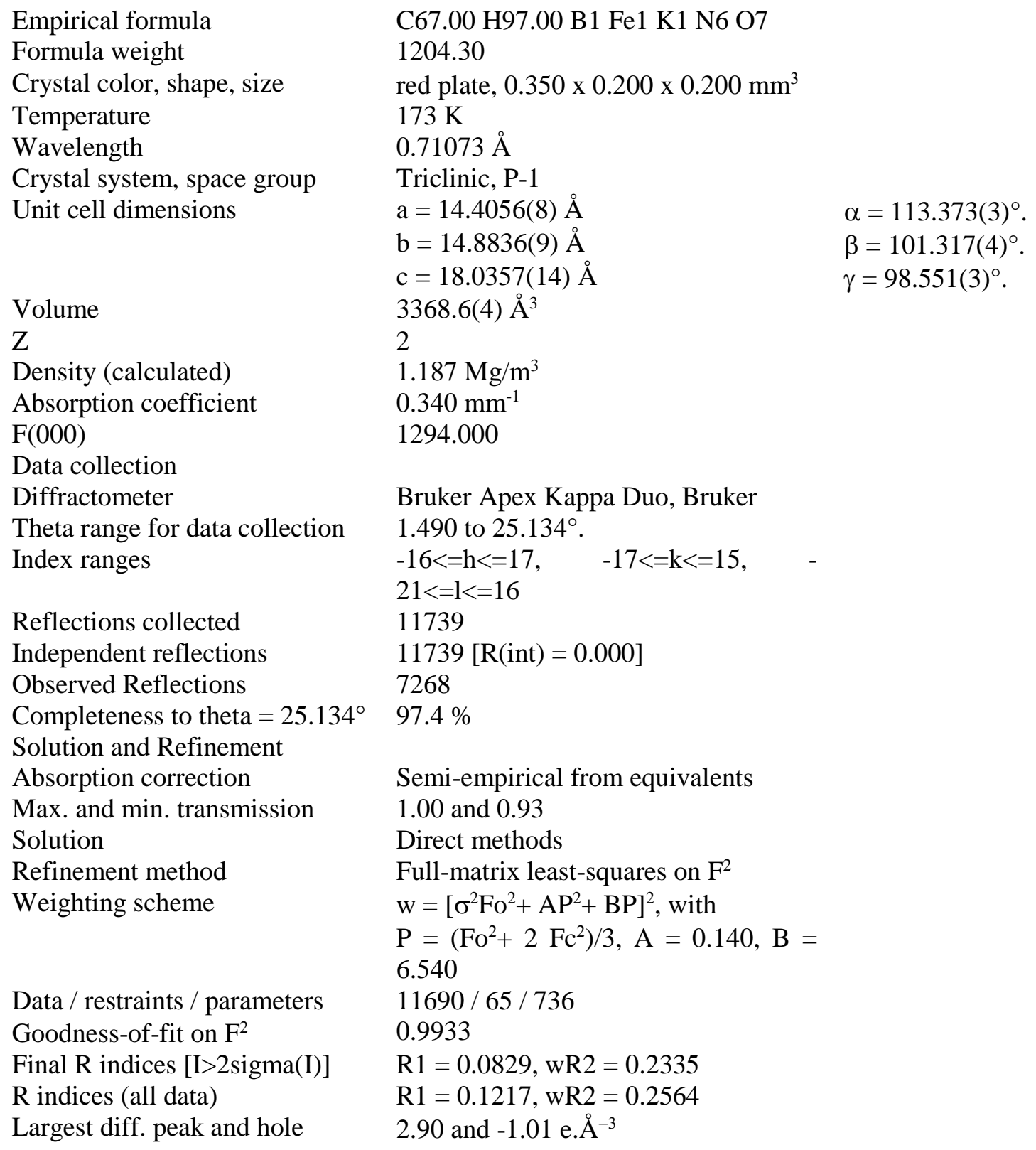




\section{References}

1 Hickey, A.K.; Lee, W.-T.; Chen, C.-H.; Pink, M.; Smith, J.M. Organometallics 2016, 35, 3069.

2 Schrock, R. R.; Fellmann, J. D. J. Am. Chem. Soc. 1978, 100, 3359.

3 Baker, M.V.; Field, L.D.; Hambley, T.W. Inorg. Chem. 1988, 27, 2872.

4 Ion Prisecaru, WMOSS4 Mössbauer Spectral Analysis Software, www.wmoss.org, 2009-2016.

5 Sirokman, G.; Molnar, A.; Bartok, M., J. Label. Compd. Radiopharm., 1989, 27, 439-448.

6 Connors, K. A. "Binding Constants: The Measurement of Molecular Complex Stability,” John Wiley \& Sons: New York, 1987.

7 Hansch, C.; Leo, A.; Taft, R. W. Chem Rev. 1991, 91, 165-196.

8 Chiang, K. P.; Barrett, P. M.; Ding, F.; Smith, J. M.; Kingsley, S.; Brennessel, W. W.; Clark, M. M.; Lachicotte, R. J.; Holland, P. L. Inorg. Chem. 2009, 48, 5106-5116.

9 Battino, R. (Ed) “Solubility Data Series. Volume 10. Nitrogen and Air” Pergamon Press, Oxford, 1982.

10 Neese, F. WIREs Comput. Mol. Sci. 2012, 2, 73.

11 Pantazis, D. A.; Chen, X. Y; Landis, C. R.; Neese, F. J. Chem. Theory Comput. 2008, 4, 908.

${ }^{12}$ Baik, M.-H.; Friesner, R. A. J. Phys. Chem. A. 2002, 106, 7407-7412.

13 SAINT, Bruker Analytical X-Ray Systems, Madison, WI, current version 
14 An empirical correction for absorption anisotropy, R. Blessing, Acta Cryst. 1995, A51, 33.

15 Betteridge, P. W.; Carruthers, J. R.; Cooper, R. I.; Prout, K.; Watkin, D. J. J. Appl. Cryst. 2003, 36, 1487. 